\title{
رمزية القرية في قصص محمد البساطي القصيرة

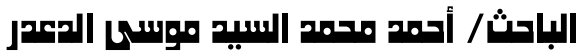

\section{ملخص:}

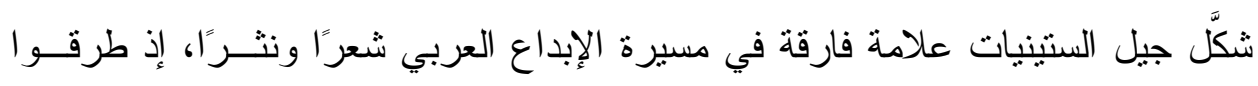

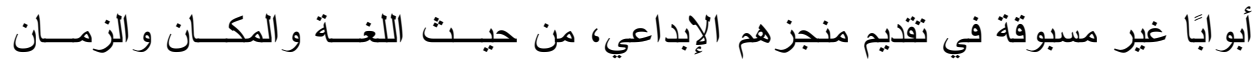
و الثخصيات، و على مستوى النثز جاءت بنية السرد لديهم متفرّدة عن سابقيهم، فأثنارت شغف الدارسين للإقبال عليها نقدًا وتأريخًا.

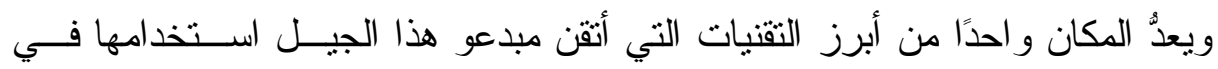

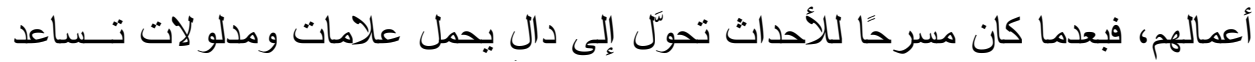

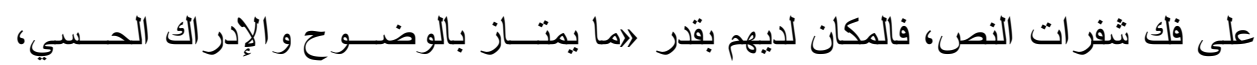
بقدر ما يتو ارى ويتعالى، ويركن إلى الغموض و المجهول على الصعيد الدلاليه" (').

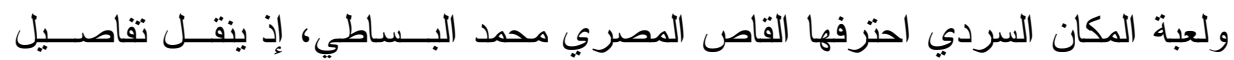

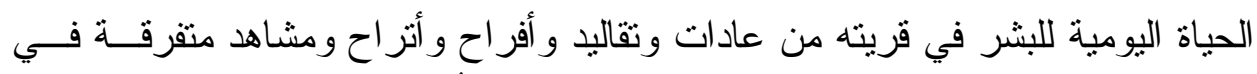

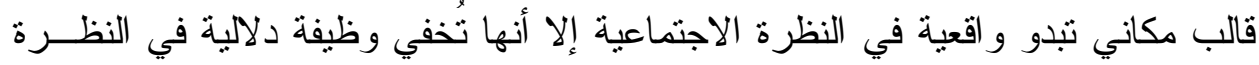

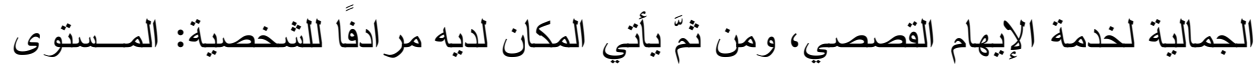

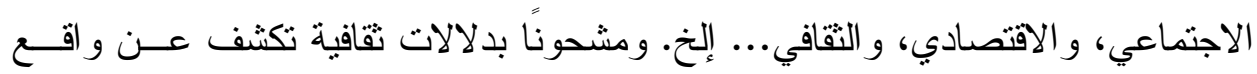
القرية المصرية آنذاك. 
The sixties generation constituted a milestone in the march of Arab creativity in poetry and prose, as they knocked on unprecedented doors in presenting their creative achievement, in terms of language, place, time and personalities.

The place is one of the most prominent techniques that the creators of this generation have mastered using in their works. After it was a scene of events, it turned into a signifier bearing signs and connotations that help decipher the text's codes .The place they have is" as much as it is characterized by clarity and sensory perception, as much as it hides and transcends, and is dependent on the mystery and the unknown. "On the semantic level"

and the game of the narrative place was mastered by the Egyptian narrator Muhammad Al-Bassati, as he conveys the details of the daily life of humans in his village of customs, traditions, joys, sorrows and scattered scenes in a spatial template that appears realistic in the social view, but it hides an indicative function in the aesthetic view of the service of fictional illusion, and then Place is synonymous with personality: social, economic, cultural...etc. And charged with cultural connotations that reveal the reality of the Egyptian village at the time. 
تحلُ القرية المصرية في مجمل منجز البساطي بوصفها مكانًا رئيسيًا و إطاريًّا عامَّــا

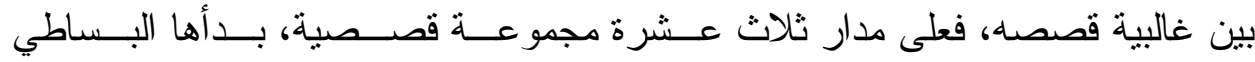

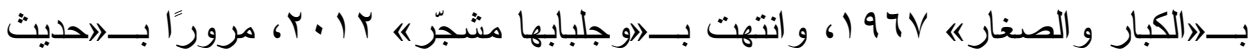

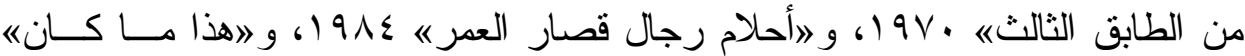

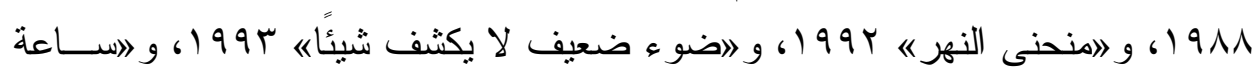

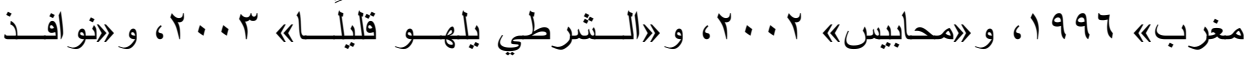

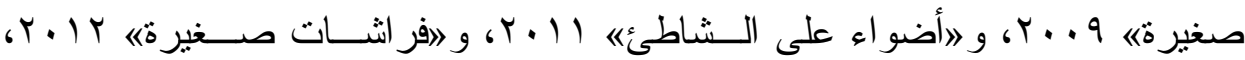
فرضت القرية حضور ها القوي على نتاجه القصصي الذي بلغ مئسـة وســتة وخمـسـين

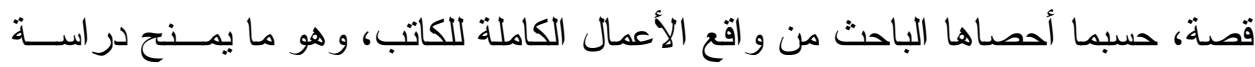
ذللك المكان أهمية وفق المنهج السيميوطيقي الذي ״لا يشتغل على المكان بوصفه بقعًّا

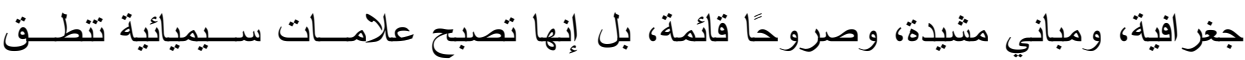
بخطابات الإنسان ودو افعه و هو اجسه الفكريةه (')

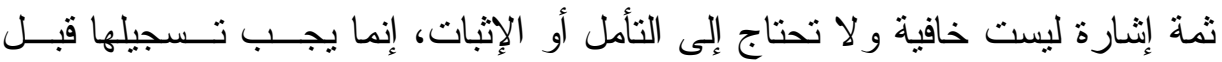

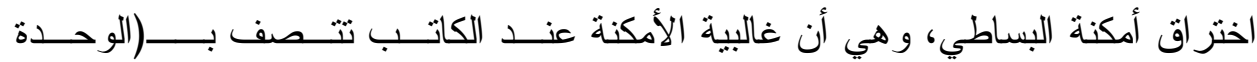

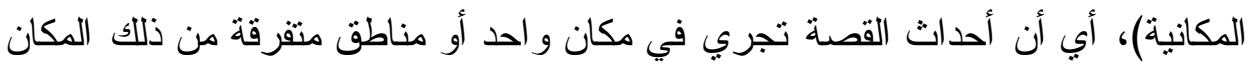

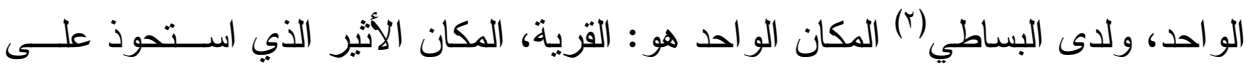

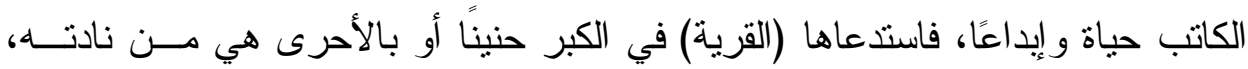

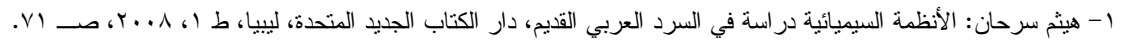

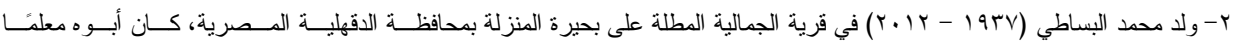

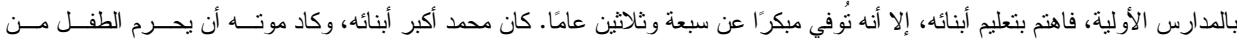

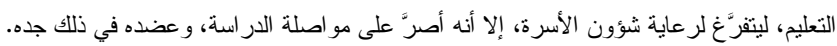

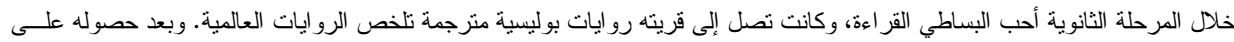

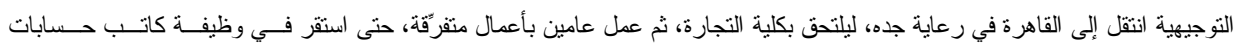

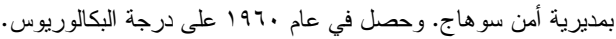

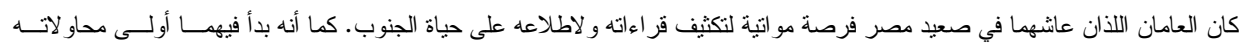

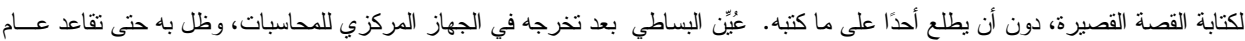


ليتخلَّص من أرق ذلك النداء المكاني بتفريغ طاقة الذكريات بالبوح الإبداعي. وهــو مــا

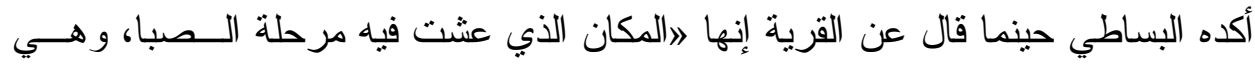

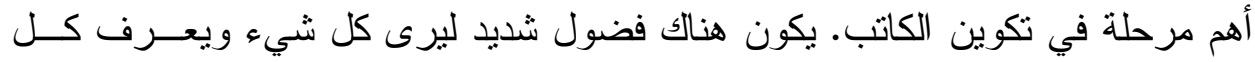

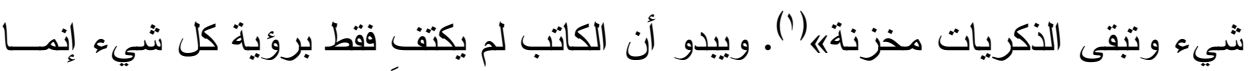

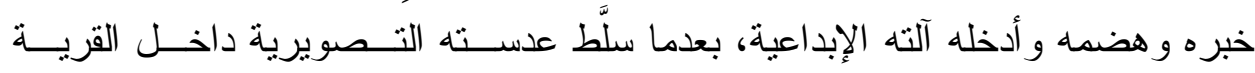
وتفاصيلها فأضاء ما كان معتمًا لمن هم خارج المكان، فأنتج منجزًا قصصيَّا إنسانيًّا.

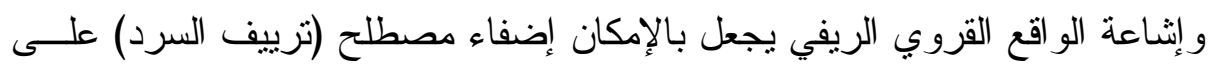

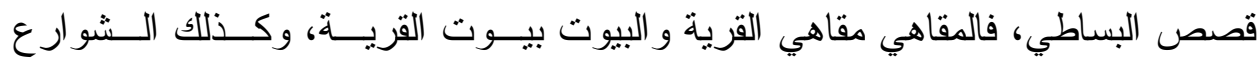

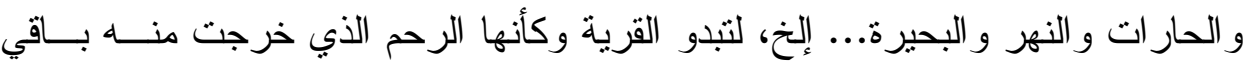

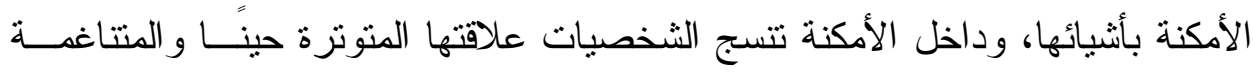

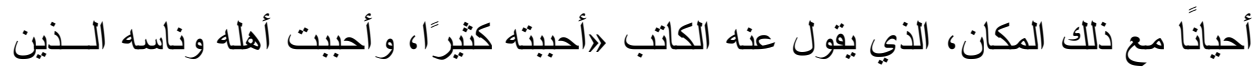

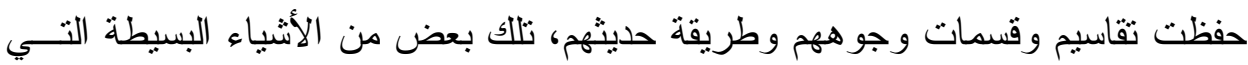

جذبتني للكتابة عنهی (؟).

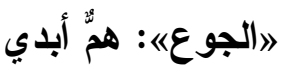

تتمظهر القرية باعتبار ها علامة مكانية سيميوطيقية تكتسب قيمتها من عـدة دلالات

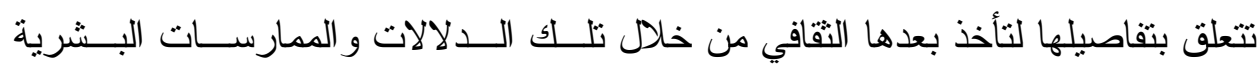

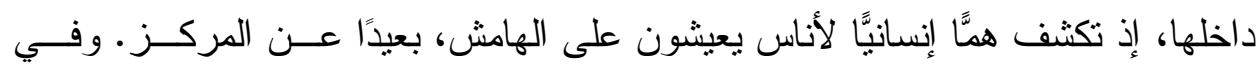

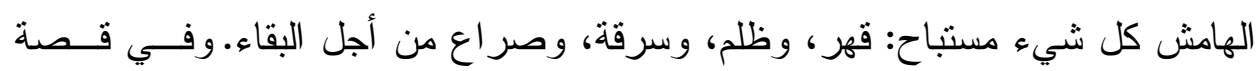

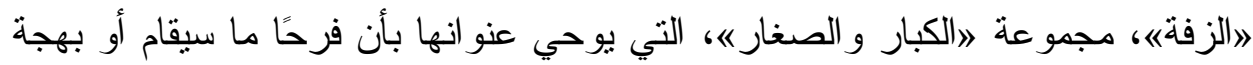

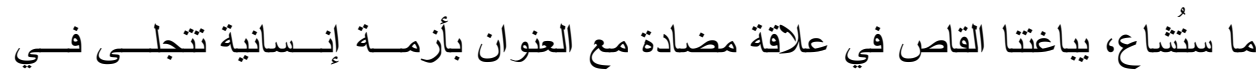

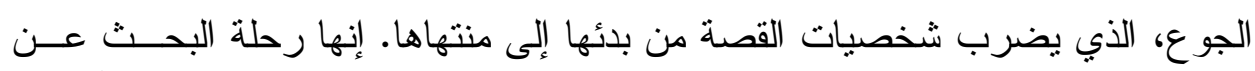

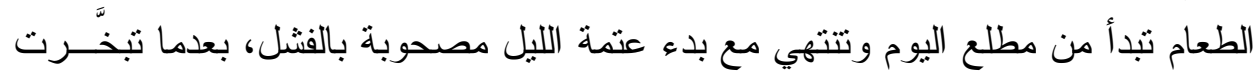
أمنيات مله البطون في نهاية القصة وسط قدوة المكان و عنفه.

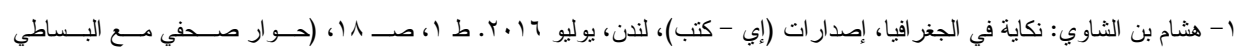
بعنو ان: محمد البساطي: نجيب محفوظ لم يؤثر على كتاب البناب الستينيات).

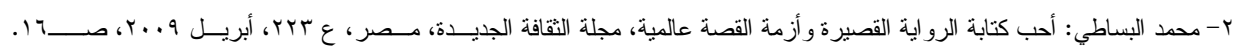


و الزفة علامة سيميوطيقية مضللة، إذ إنها زفة من دون فرح، وضـــيج مــن دون

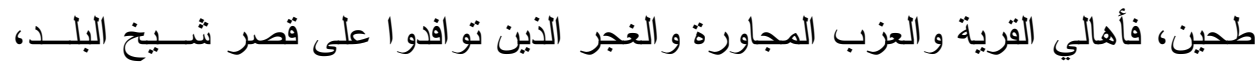

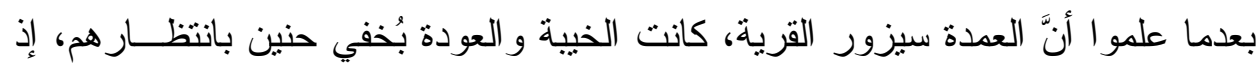

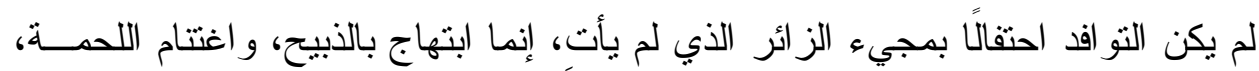
التي سيفرقّها شيخ البلد على الأهالي فرحة بشفاء العددة من جر احة الكبد.

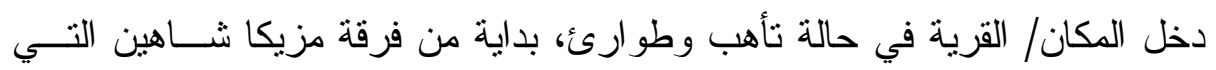

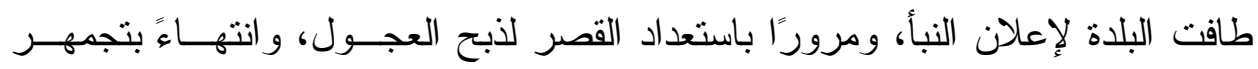

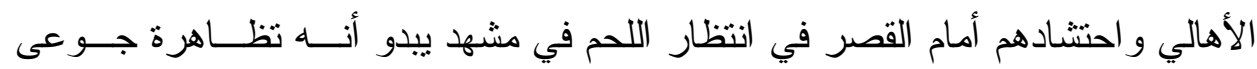

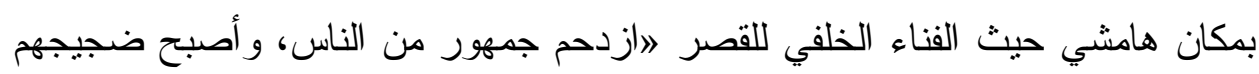

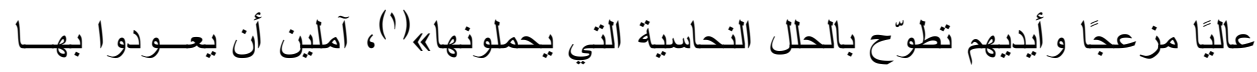

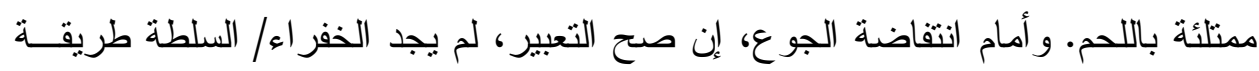

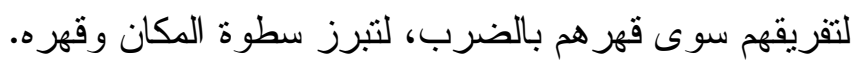

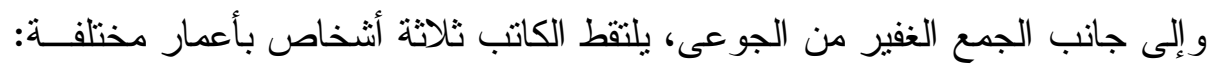

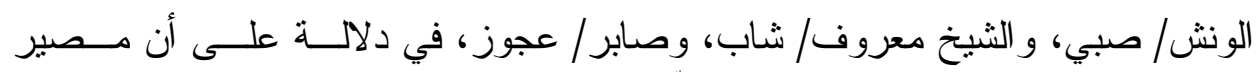

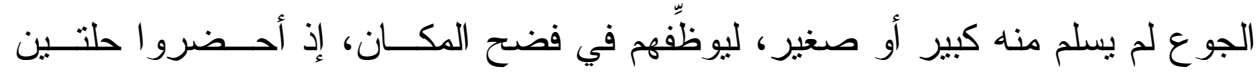

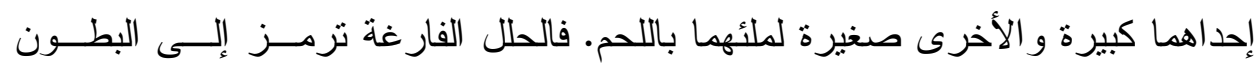

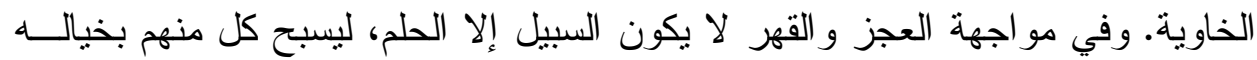

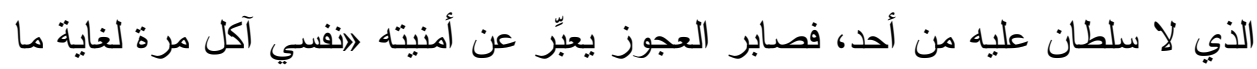

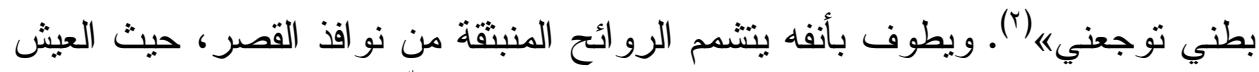

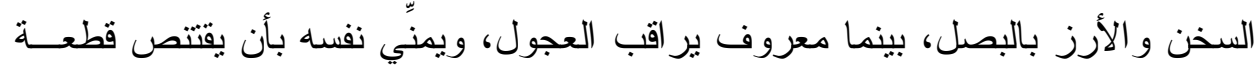

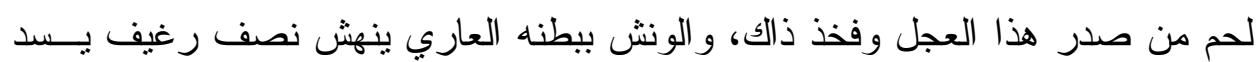

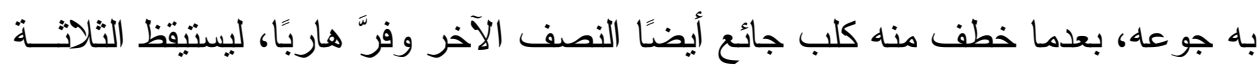

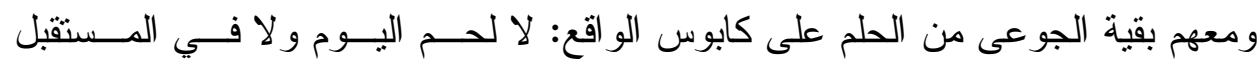
القريب. 
وبينما تبدأ القصة بمكان مشبَّع بالطاقة و الحيوية على إثر نبأ زيارة العمــدة للقريــة،

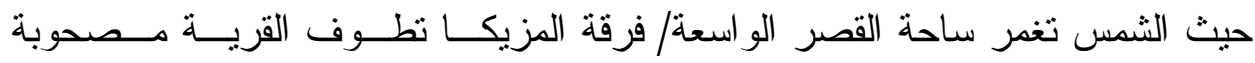

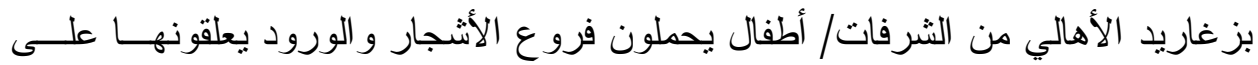

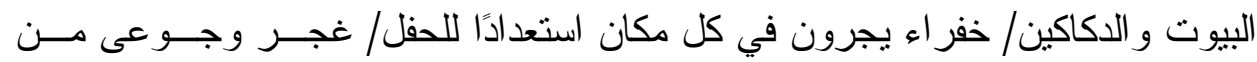

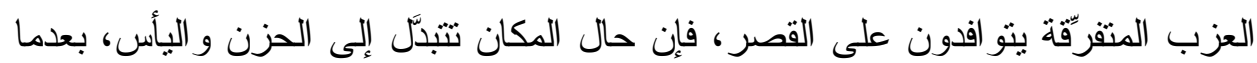

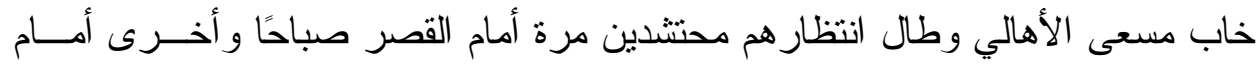

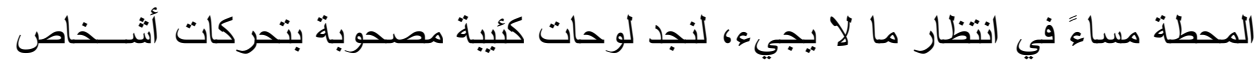

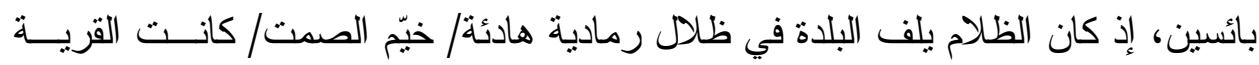
هادئة/ بدت القرية ساكنة هامدة، ليمنحنا القاص صورة بانور امية لمشهر الجوع الأبـدي ليدي

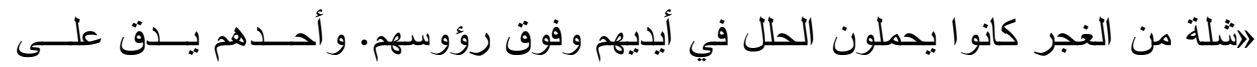

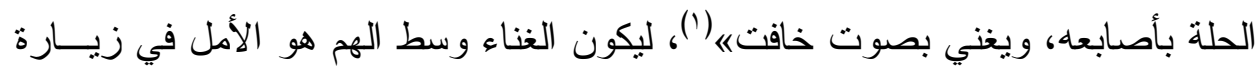
قريبة، تمنلئ معها البطون.

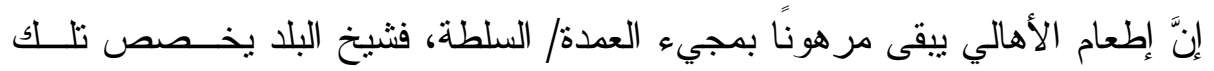

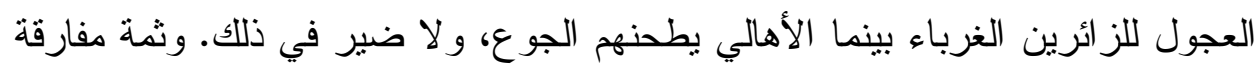

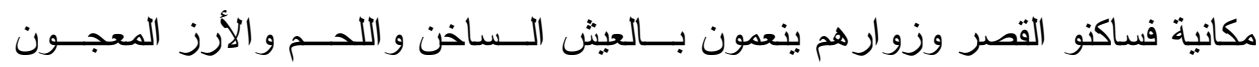
بالبصل... إلخ، في دلالة على أن من بيكن القصر آمنٌ من الجوع و والحاجة، بينما مــن

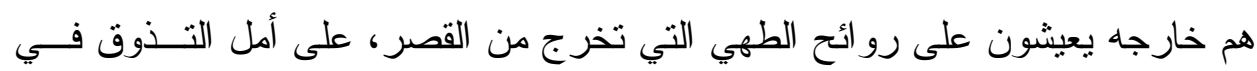

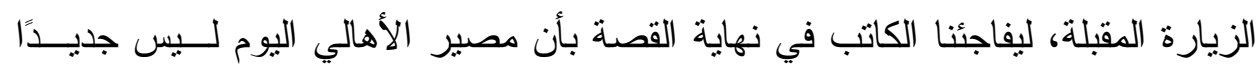

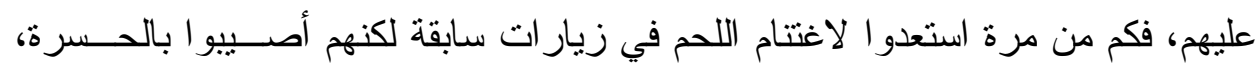

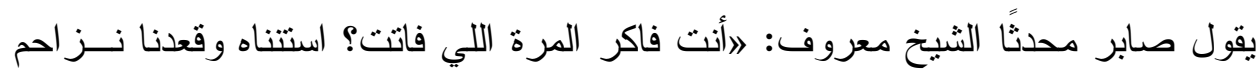

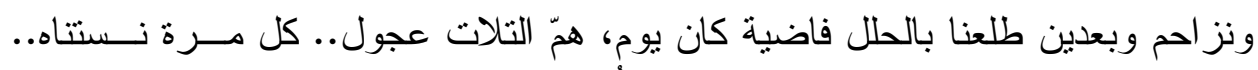

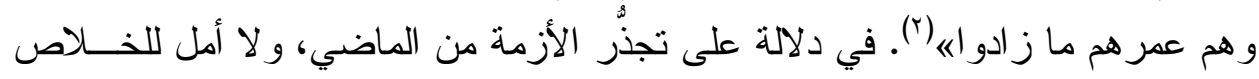

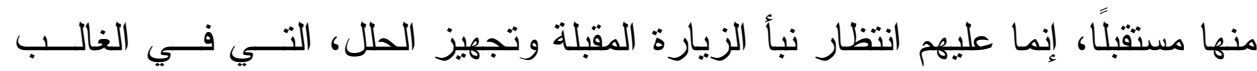

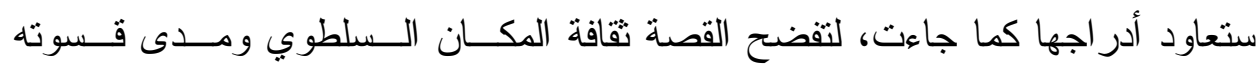
وبشاعته تجاه ساكنيه. 
| إمعركة الرزقش: صراع البقاء

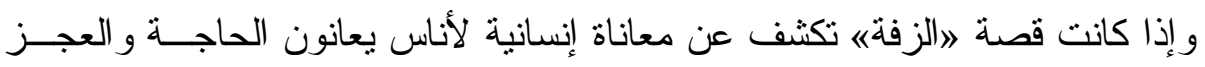

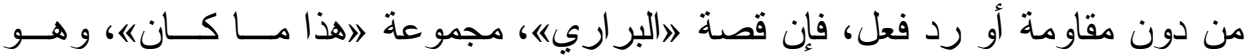

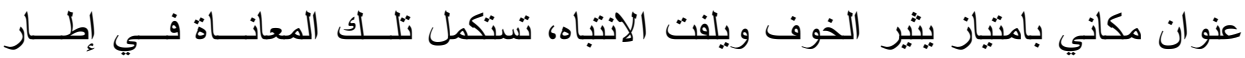

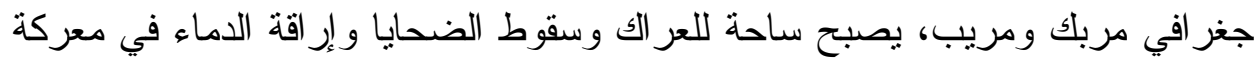

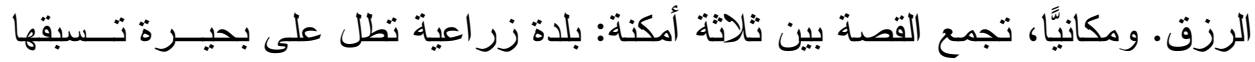

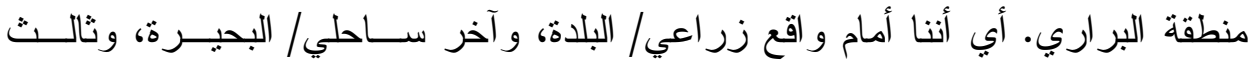

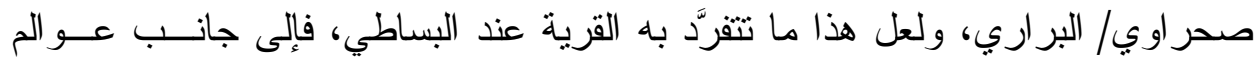
الفلاحين نجد حياة الصيادين و العمال، لتتضافر جميعها داخل مكان و احد، يجسّّد مآسيهم من ناحية، وسيكولوجيتهم من ناحية أخرى.

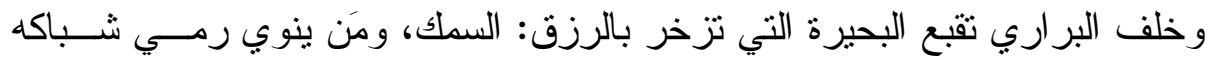

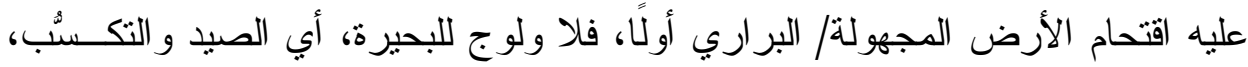

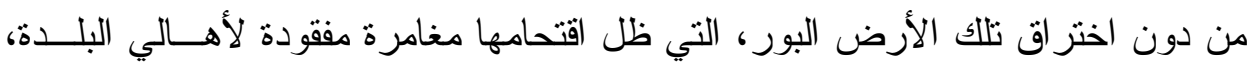

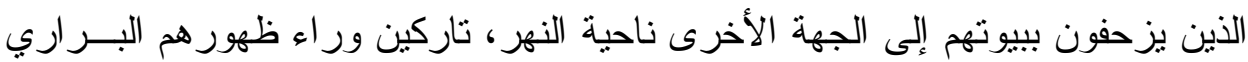

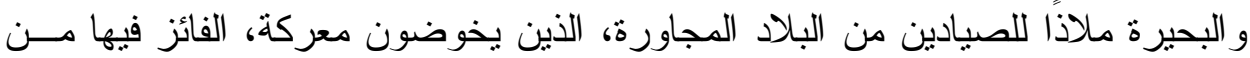
بستحوذ على المكان. وحينما يبدأ السمك في الانحسار يشتعل العر الك بين الصيادين، الذي يخلِّف ضـــايا

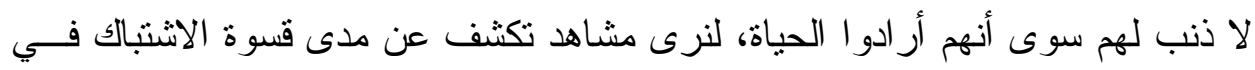

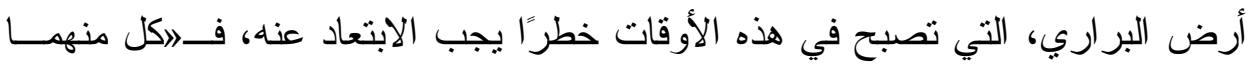

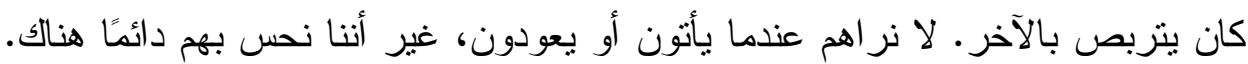

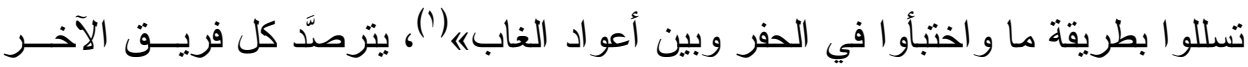

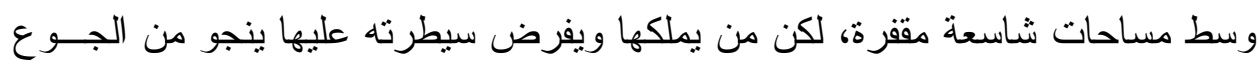
و الهالك، و النتيجة جرحى تحملهم العربات الكارو وتر افقهم النسوة متشحات بالسو اد إلى عنى

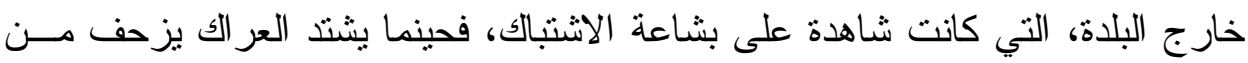

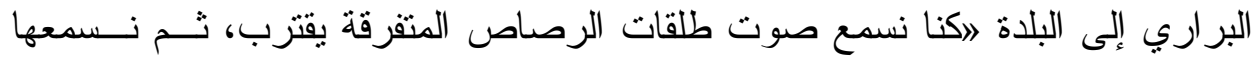

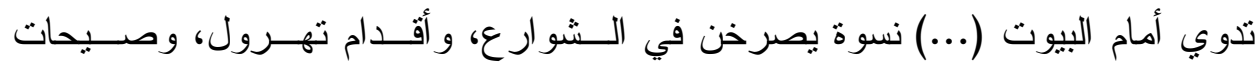




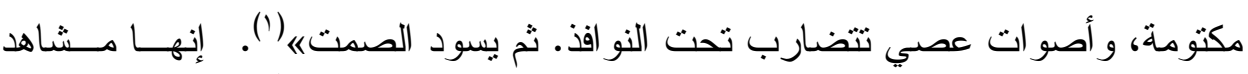

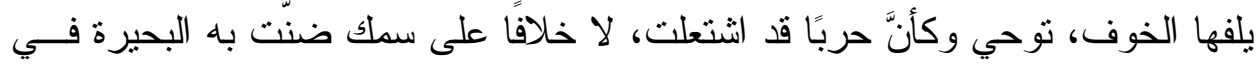

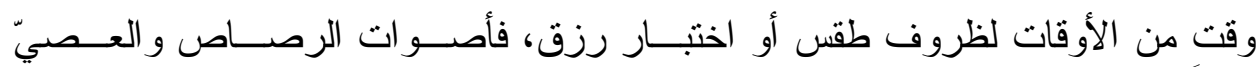

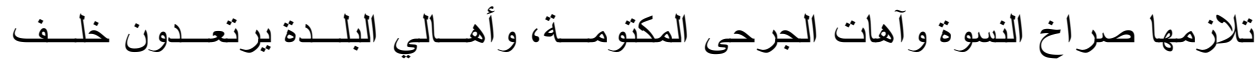

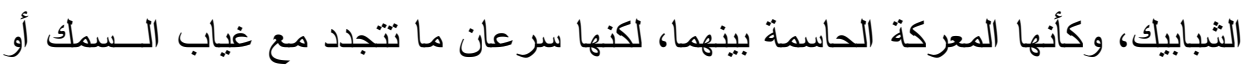
قلته. إنَّ البر اري علامة سيميوطيقية أو متاهة مكانية غامضة بأرضها المكـسوَّة بــالملح

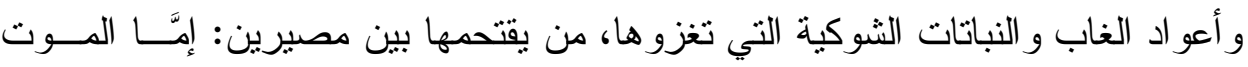

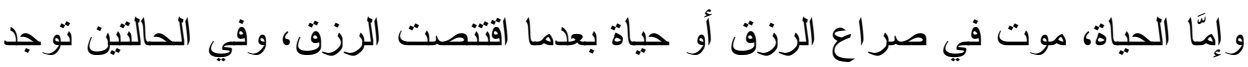

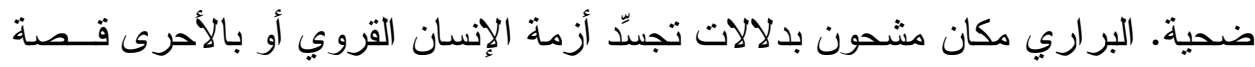

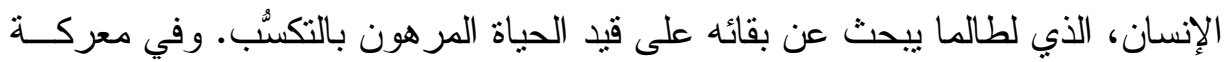

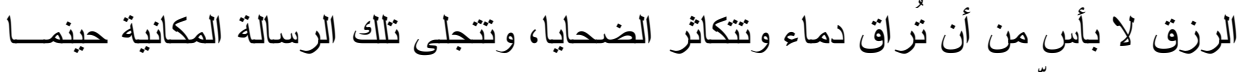

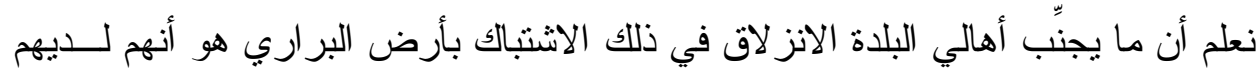

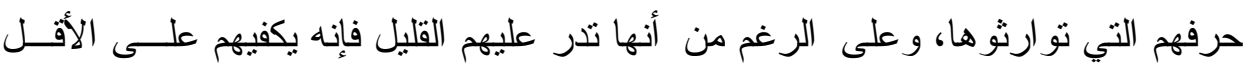

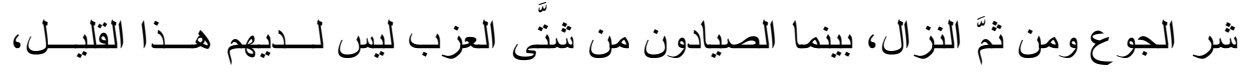

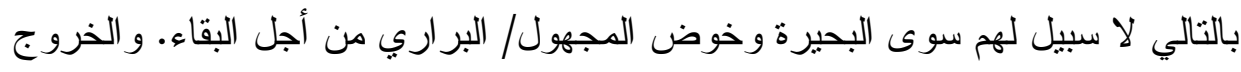

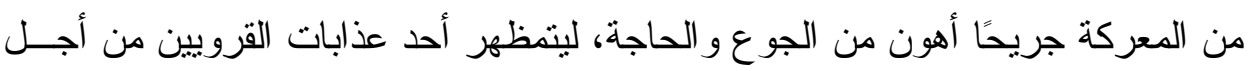

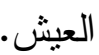

\section{》الاغتر اب«: المكان مرآة الذات}

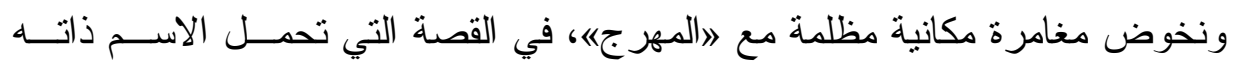

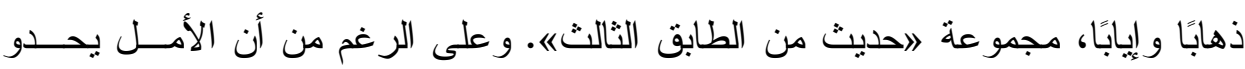

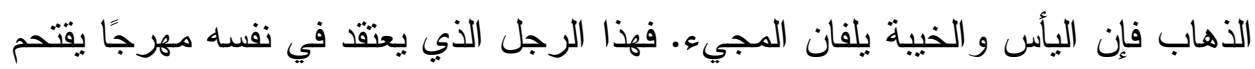

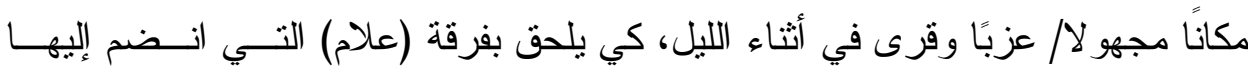

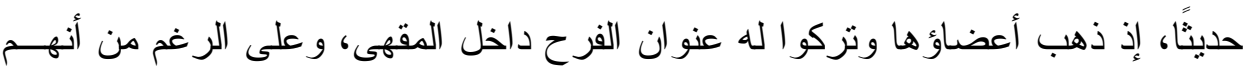

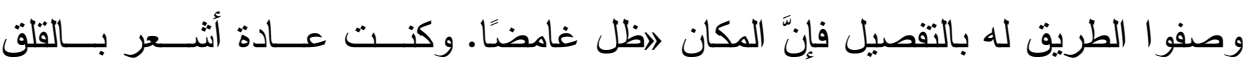




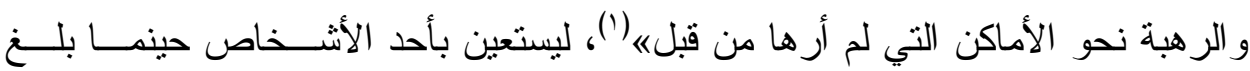

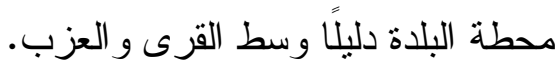

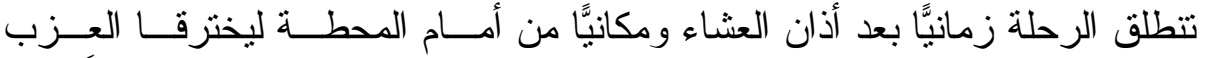

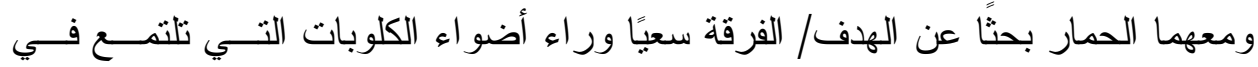

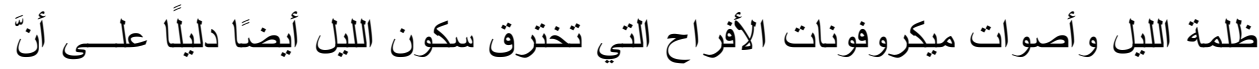

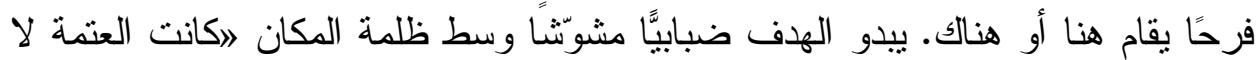

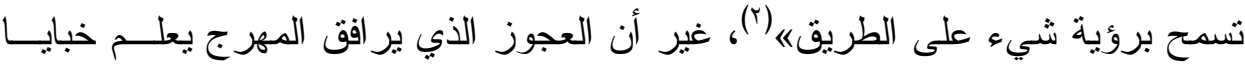

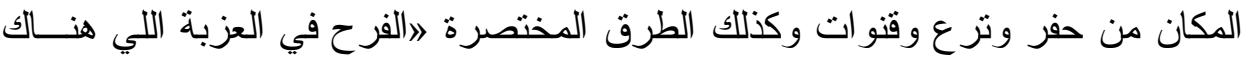

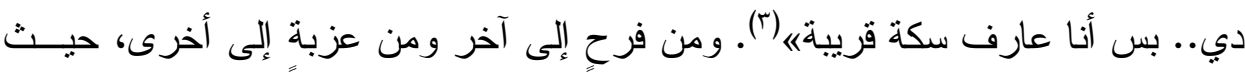

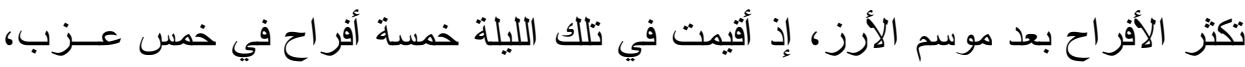

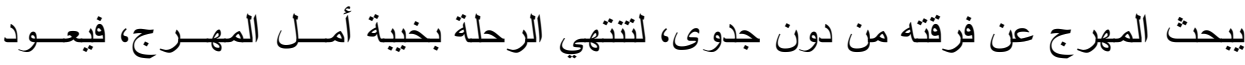

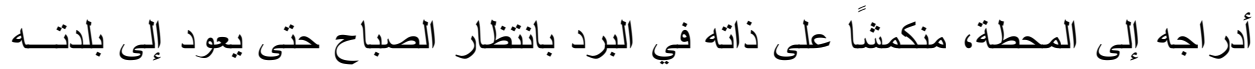

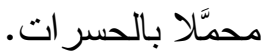

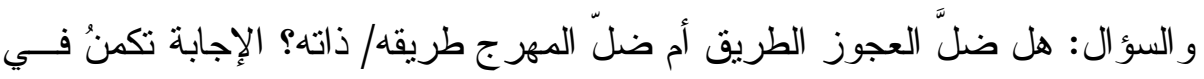

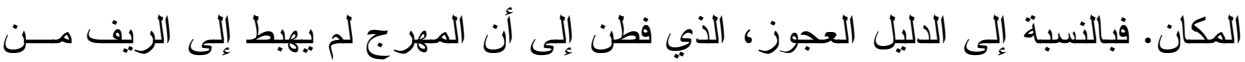

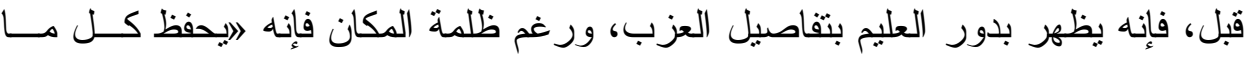

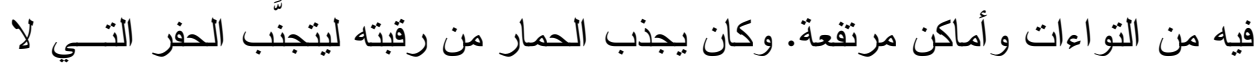

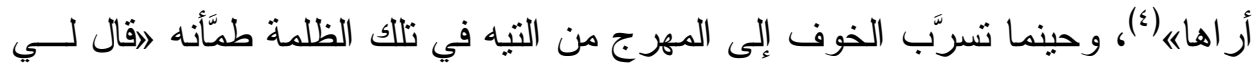

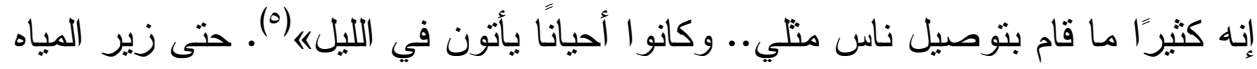

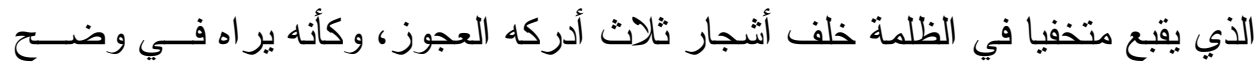

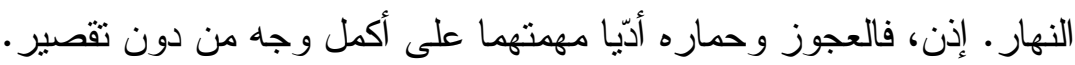

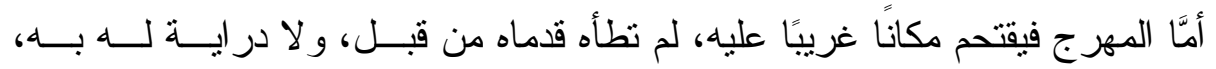

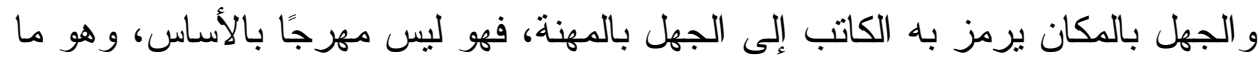

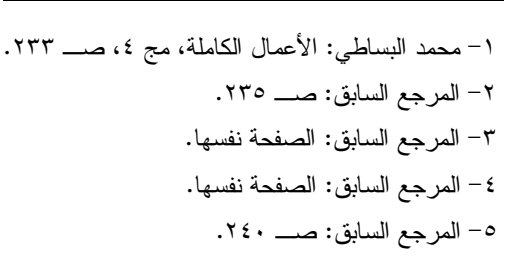


و اجهته به الفرقة التي اختبرته القد قالو الي إن شخصنًا له طبيعتي لم يكن له أن يقـوم

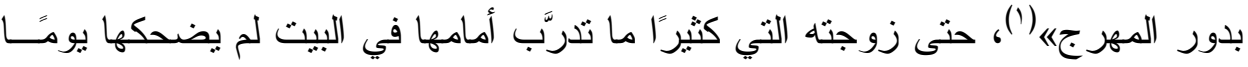

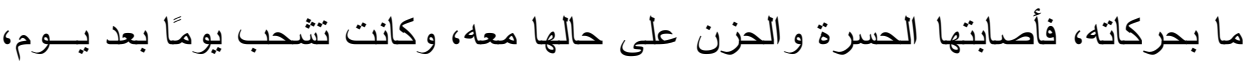

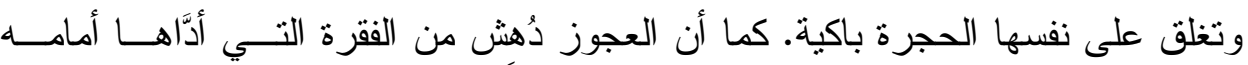

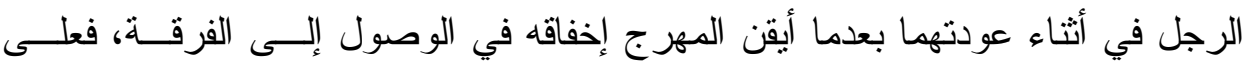

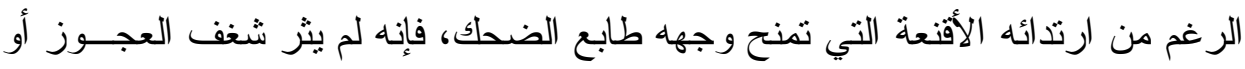

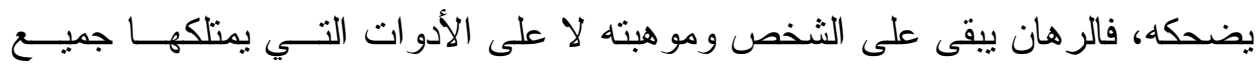

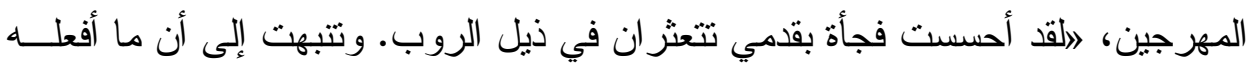
كان شيئًا أثبها برقصة مضطربة. وكان هو (العجوز) يرمقني صامتاً من خلف حماره.

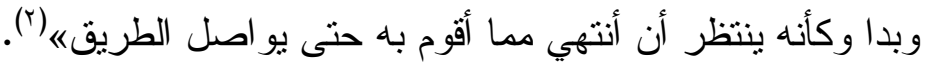

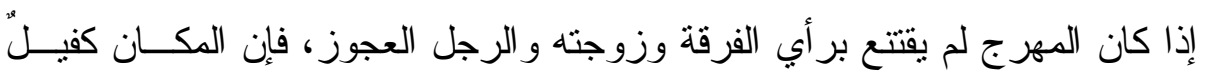

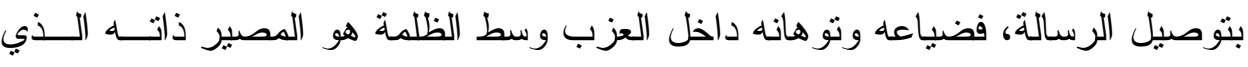

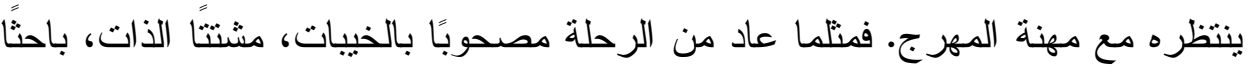

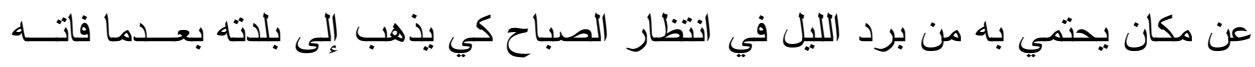

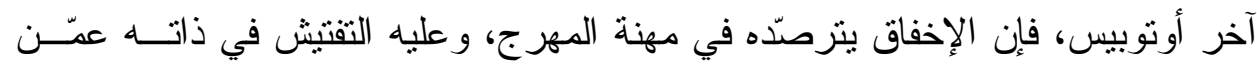
يكون قبل فو ات الأوان. إن الثتات الذي تعانيه الثخصية بدا جليَّا في انعكاساته على المكـــان، فـسيميوطيقا

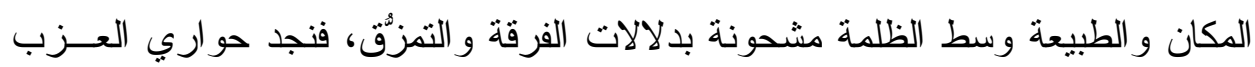

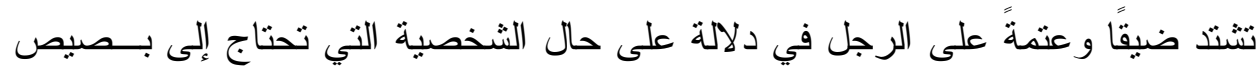

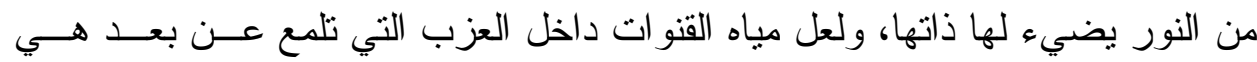

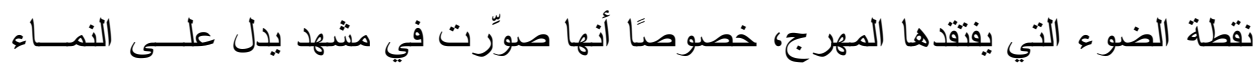

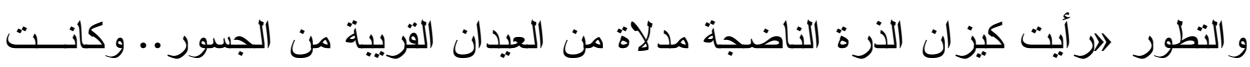

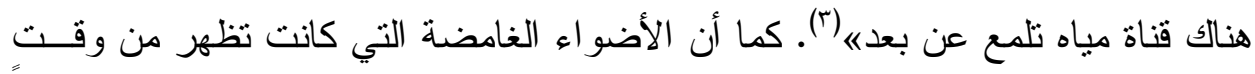
إلى آخر على الطريق، فسمحت للمهرج برؤية المكان من حوله ترمز إلى حاجته أيضًا 


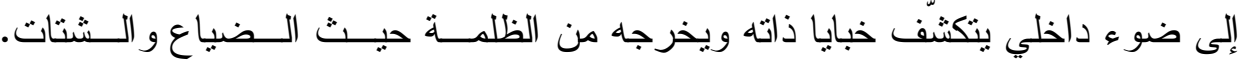

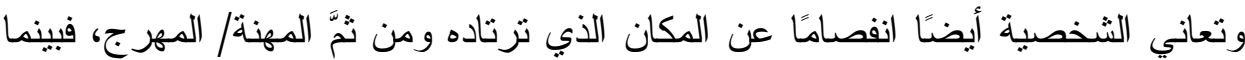

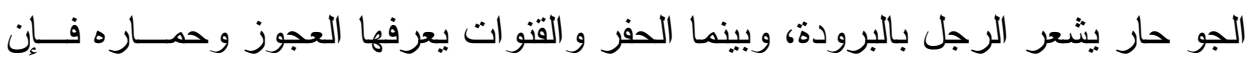

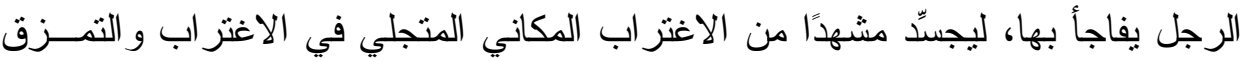
الذاتي، ليأتي المكان في النص بمتاهاته المجهولة راسمًا مصير الثخصية التي تعساني التيه.

\section{الاحتماء بالمكان}

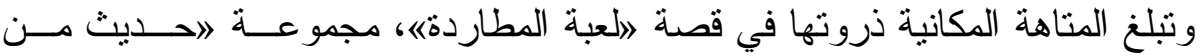
الطابق الثالثه، ففي القصة يدفعنا الكاتب إلى حقول القصب و الذرة، لنغوص في ظلمة

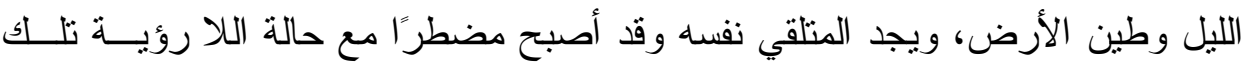
إلى أن يفعّل حاستي السمع و البصر إلى جانب القر اعة، حتى يتمكّن من مجار اة المكان،

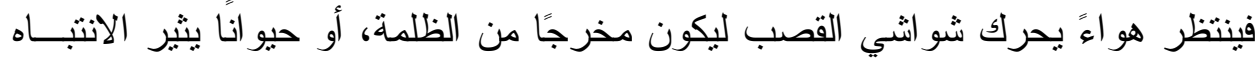
بقز اته بين أعو اد الذرة فيكون دليلًا.

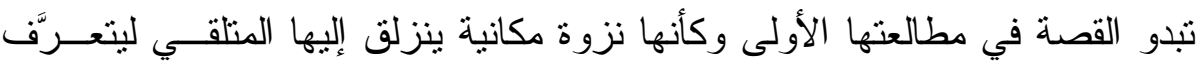

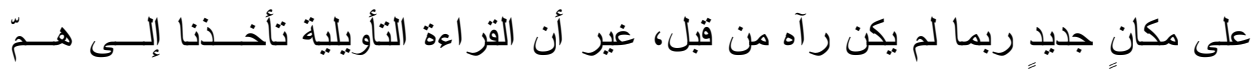

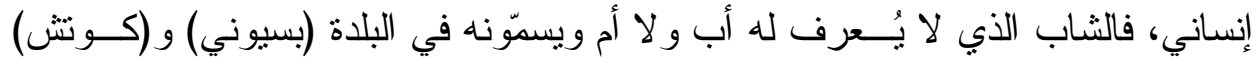

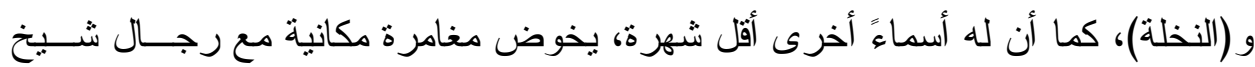

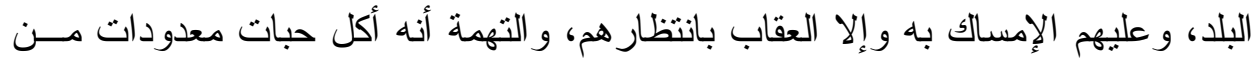

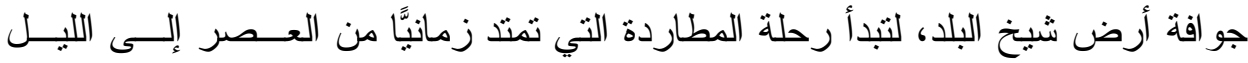

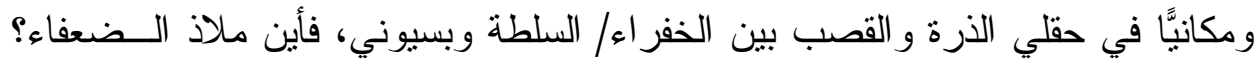
الملاذ هو المكان، الذي خَبره بسيوني جيدًا وتلاعب بشيخ البلد وخفر ائه داخله.

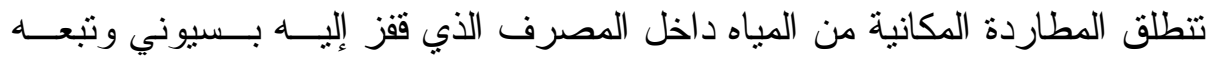

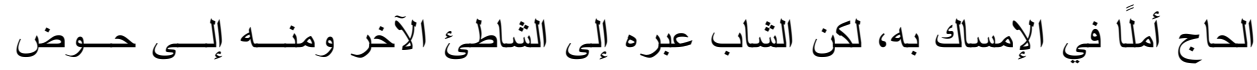

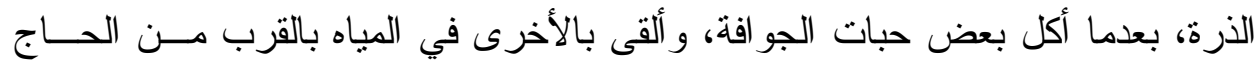

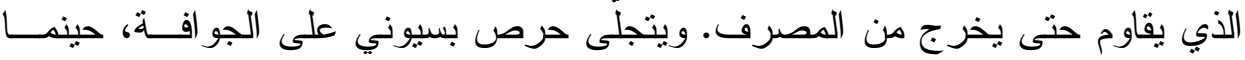
يدفن ما تبقى منها داخل حوض الذرة، في دلالة على أن الخوف من الجوع أبقى أثـــرًا

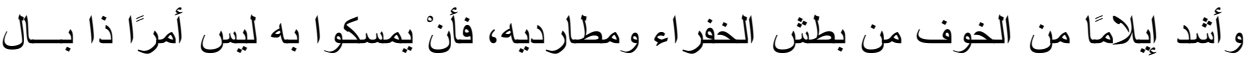




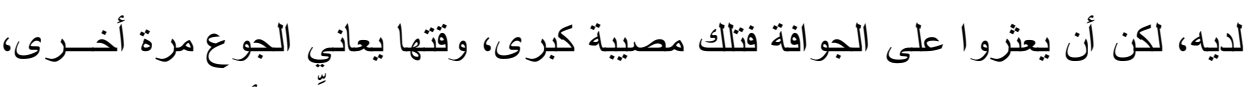

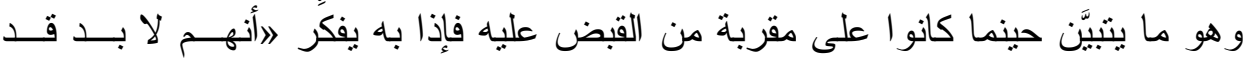

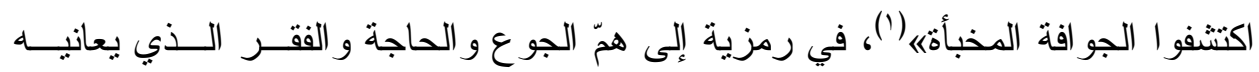
المجتمع القروي عمومًا، وبسيوني خصوصنًا. وبينما الخفر اء ينظرون إلى العيدان في صمت وتزرقب، وكأنهم في انتظار حركة أو

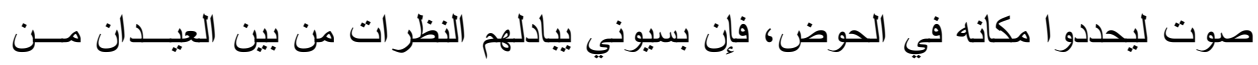

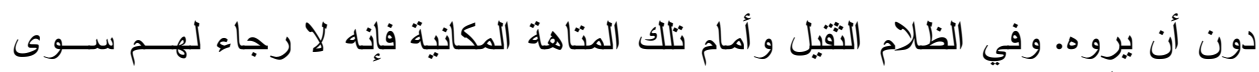

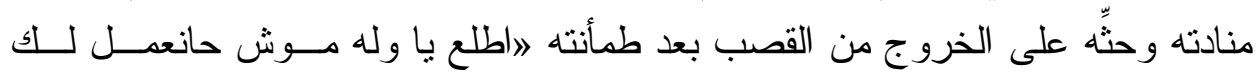

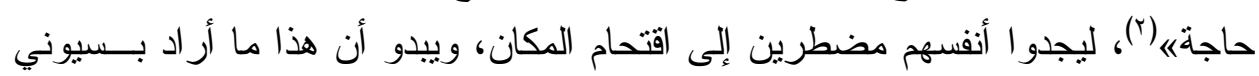

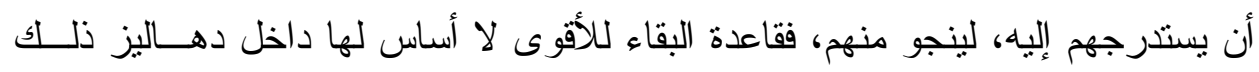

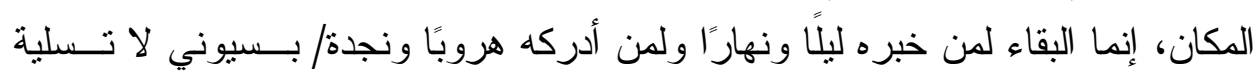
ور احة/ الخفر اء.

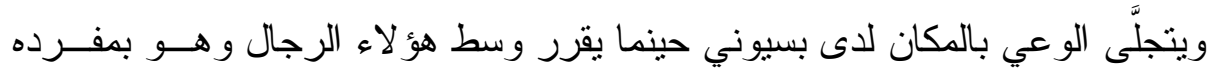

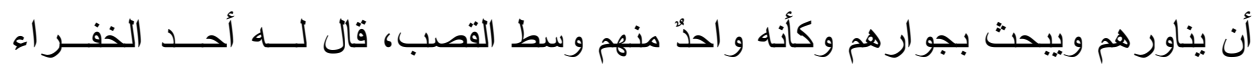

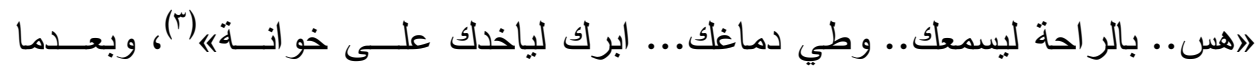

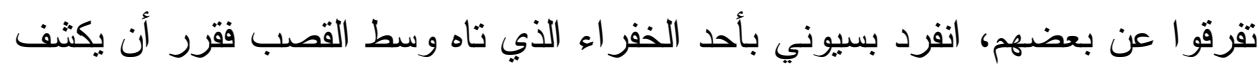

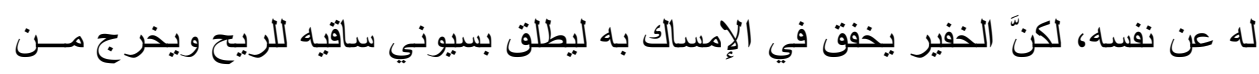

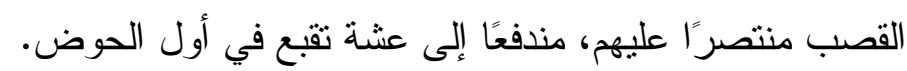

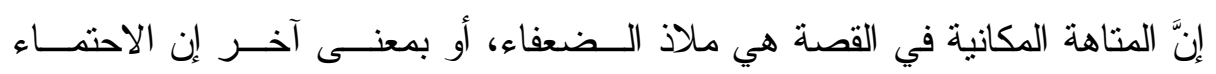

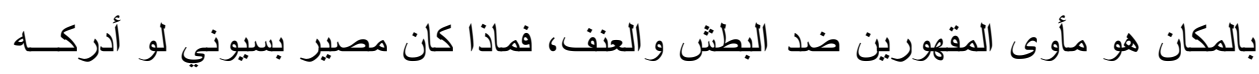

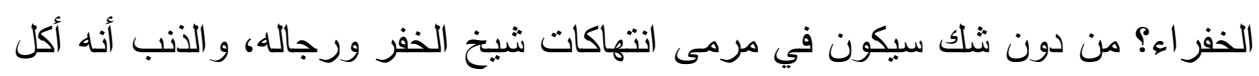

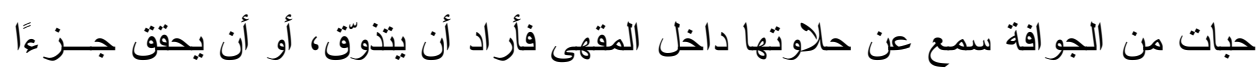

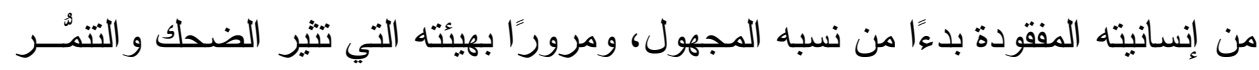

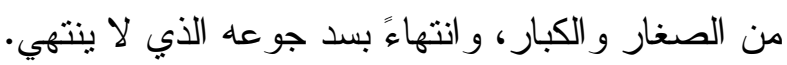


وتتمظهر تقنية الاحتماء بالمكان في قصص عدة لدى البساطي، ففي قصة اضـــوء ضعيف لا يكثف شيئاه، التي تحمل المجموعة اسمها، نجد القرية التي لم تعلم أن ثورة باءئ

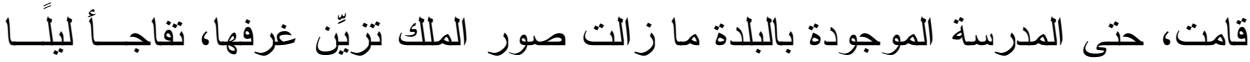

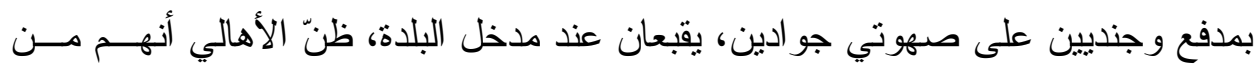

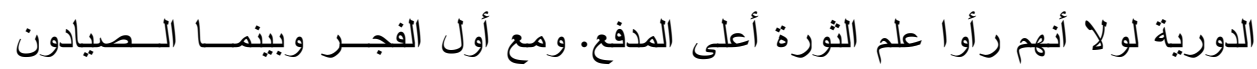

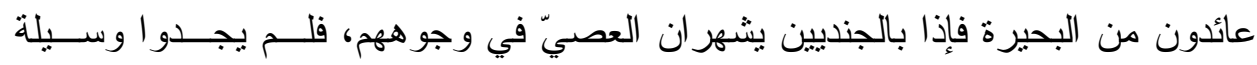

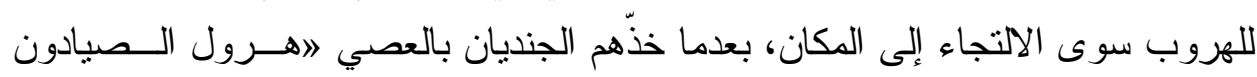

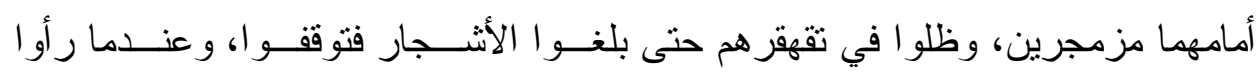

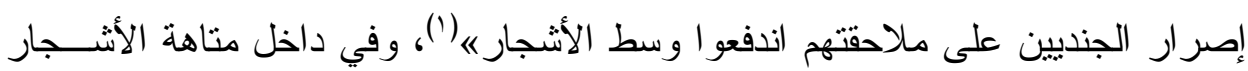

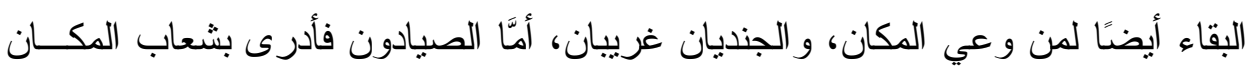

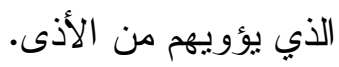

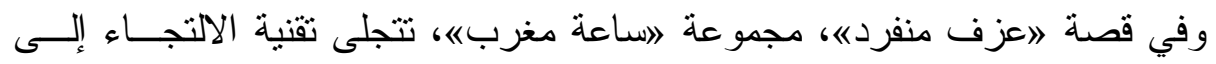

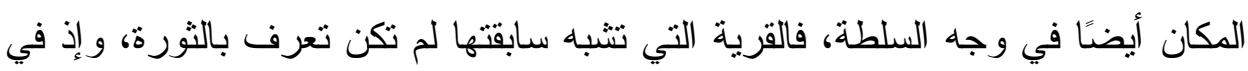

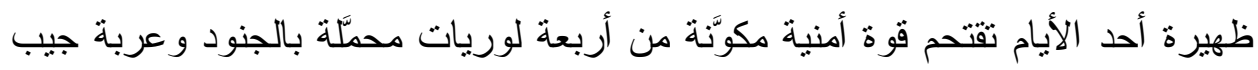

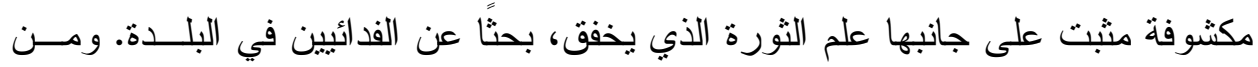

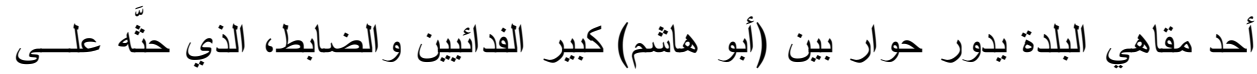

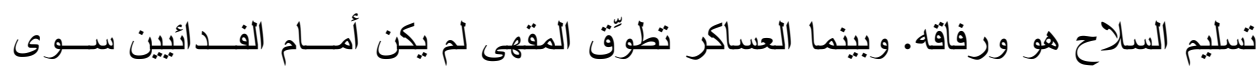

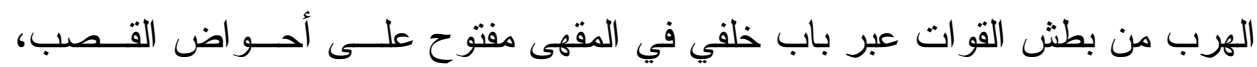

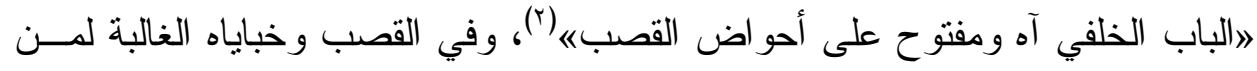

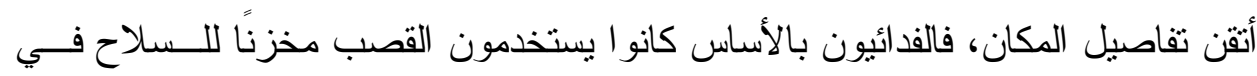

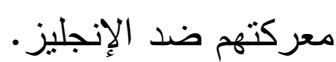

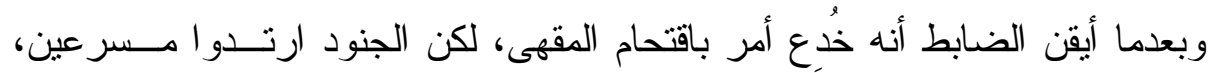

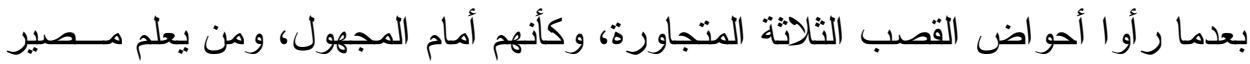

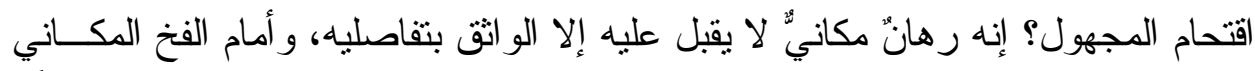

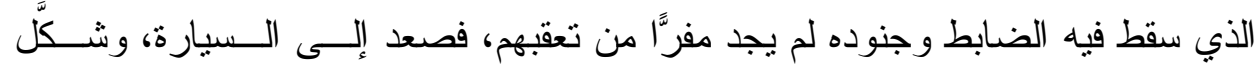


طابوراً وساروا في الطريق الجانبي لأحو اض القصب. لكن، تبقى العقبة المكانية قائمـــة

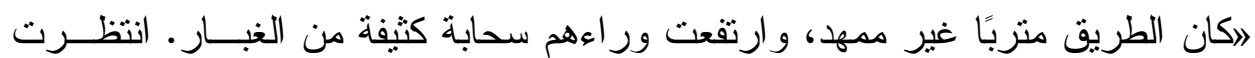

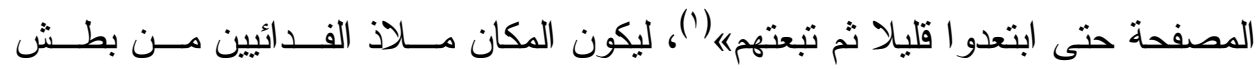
الجنود، وسببًا في إخفاق الضابط المكلف في مهنته.

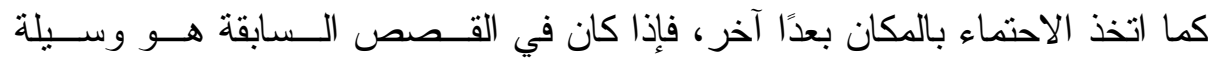

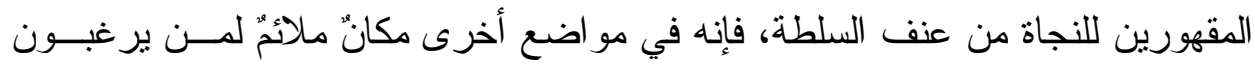

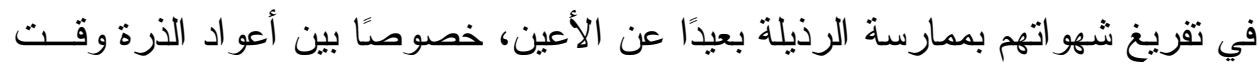

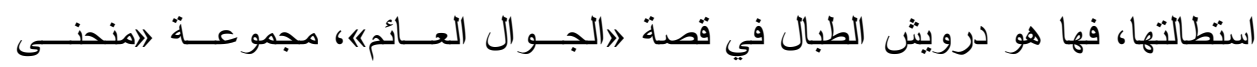

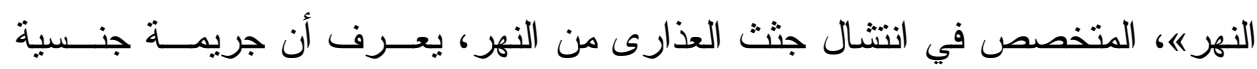

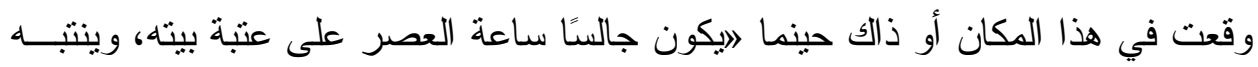

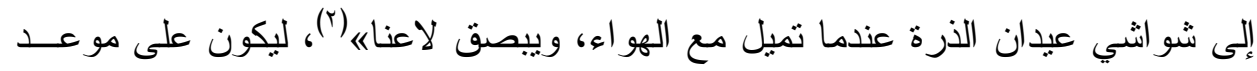

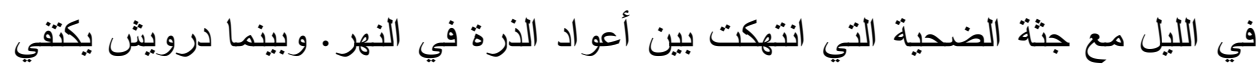

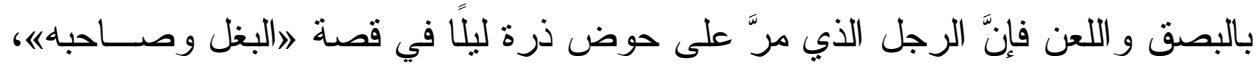

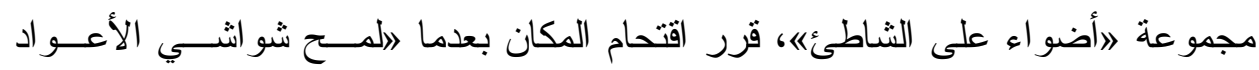

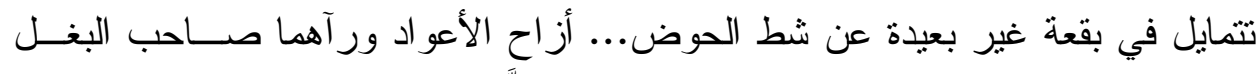

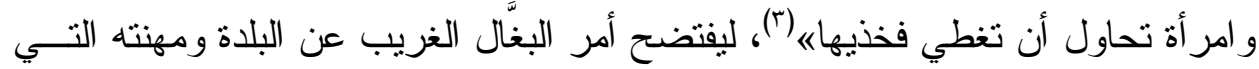

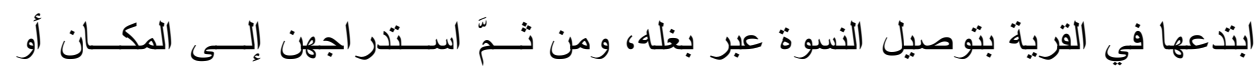
بالأحرى يتو افق هو اهما/ البغال و المر أة فيكون المكان ملجأهما.

\section{رسائل سياسية}

وبعيدًا من المتاهات المكانية المُلغزة، يحل المَجْرى في القصـة التي تحمــل العنــــــان

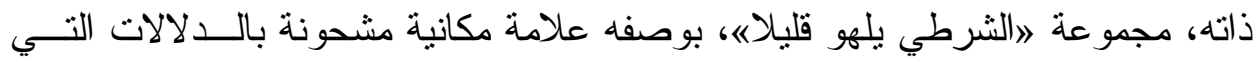
تبرز مدى الثتات و الفرقة و النزاع الذي أصاب مصر الثورة. ينشطر زمن القصة بــين

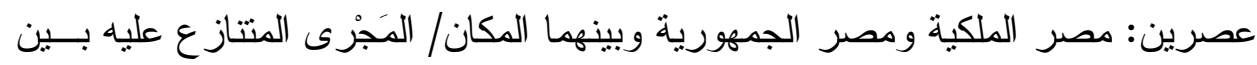

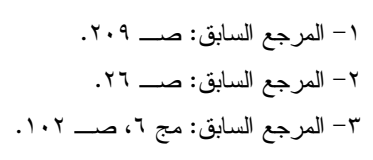


عمال الحفر وعمال الردم، الذي كان مقدرّا لله أن يبدأ من النهر خــارج البلــدة متخـــاً طريقه وسط (الأرض البور) لينتهي إلى البحيرة.

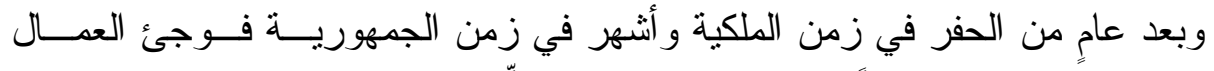

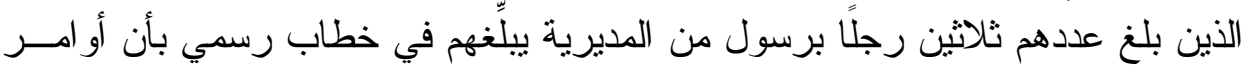

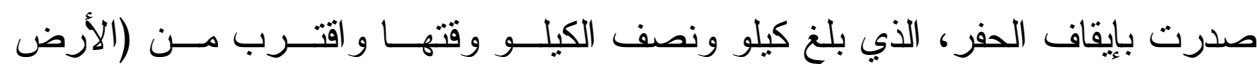

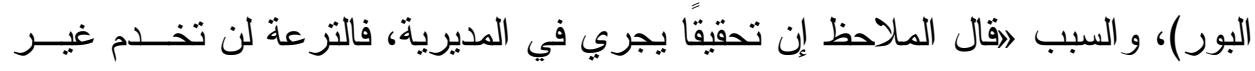

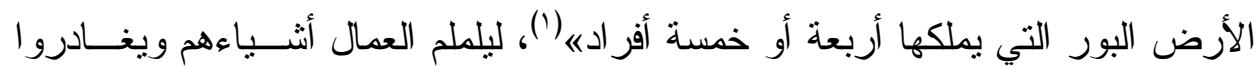

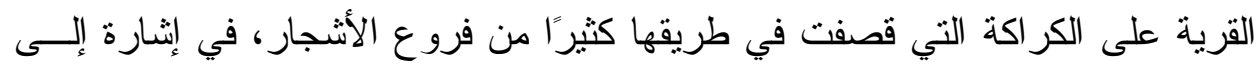

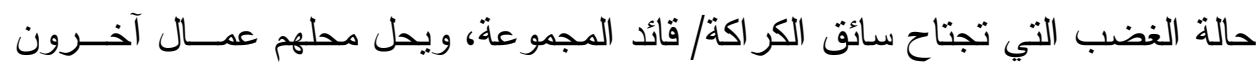

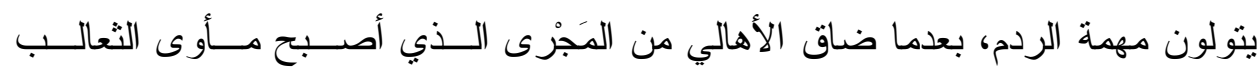
و الثعابين التي أخذت تزحف إلى الى البلدة من خلالها

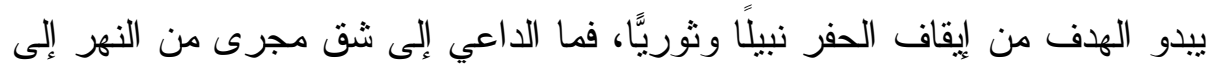

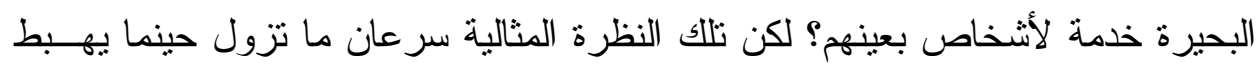

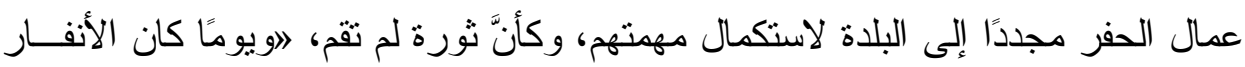

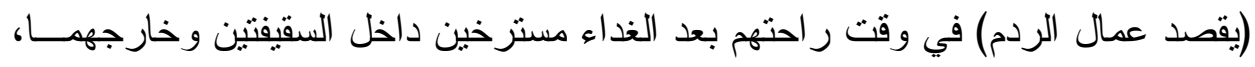

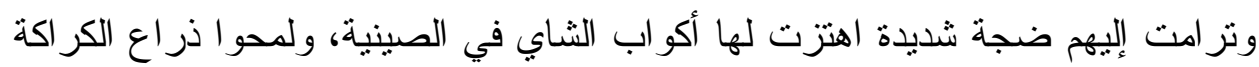

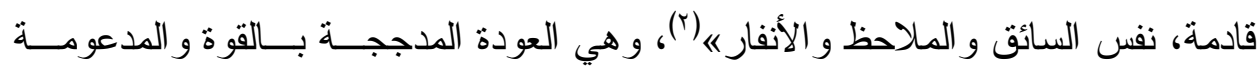

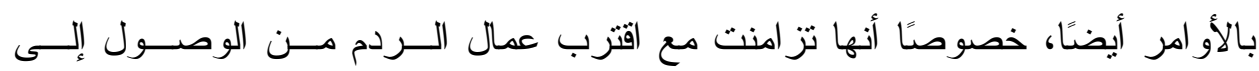

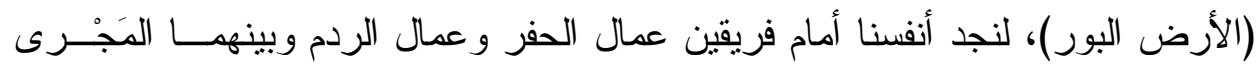
المتناز ع عليه. ولعل القاص برمز إلى المَجْرى بالوطن، وعمال الحفر و الردم هم مــن بيتــازعون

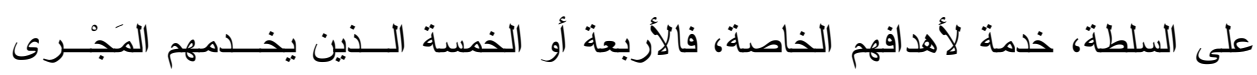

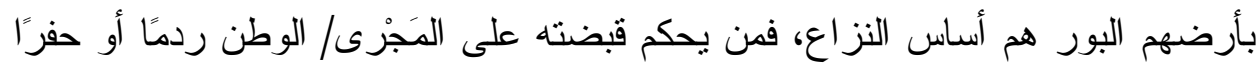

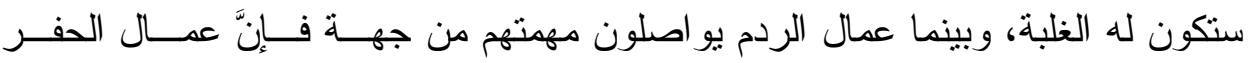

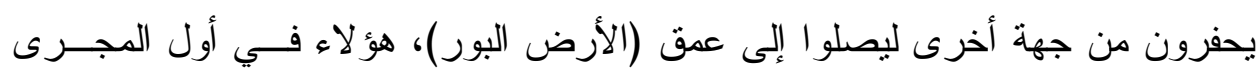




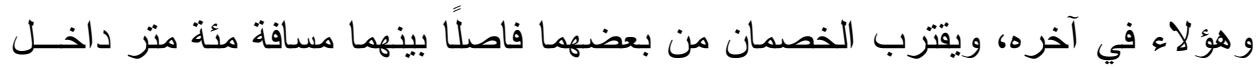
المجرى، فيؤثر ملاحظ الردم وقف العمل يومين لحين ابتعادهم.

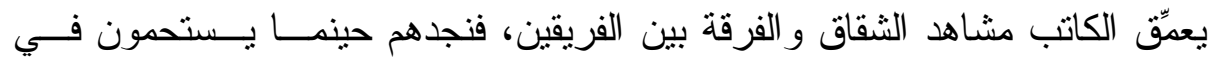

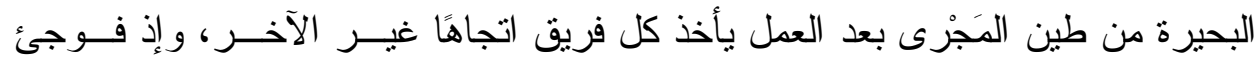

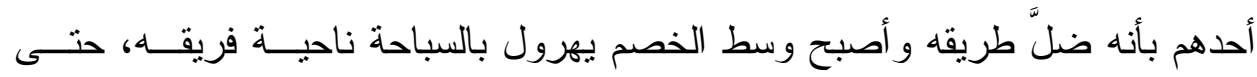

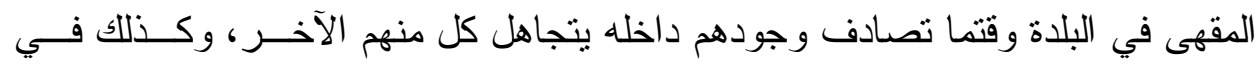

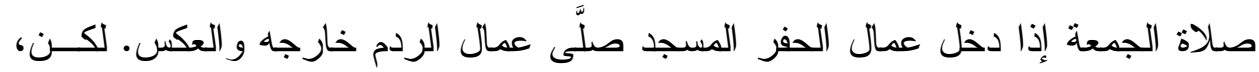

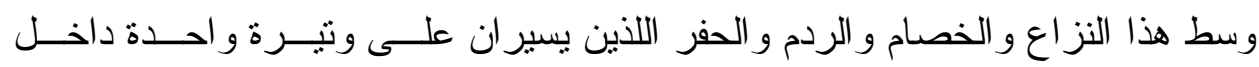
المَجْرى/ الوطن لمن تكون الغلبة؟

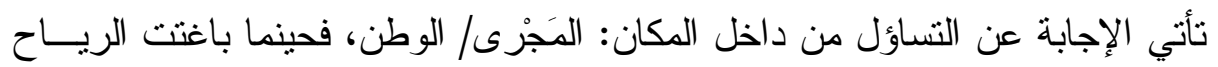
عمال الفريقين في أثناء عملهم، تلاك الريح التي رأوها القادمة على بعد معنمة بما حملته

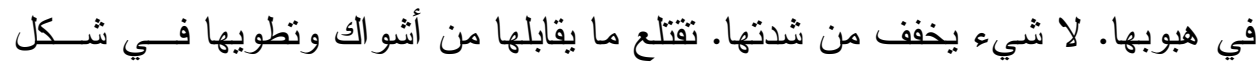

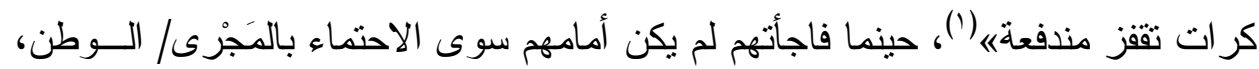

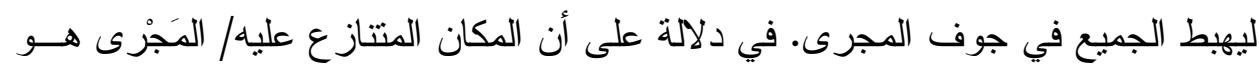

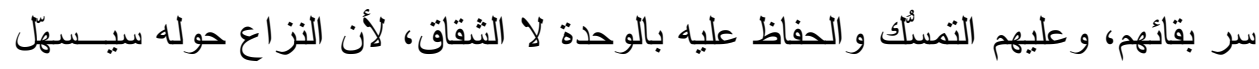
مهمة الأغيار / الرياح عليه. و على الرغم من الخطر الحادث فإن الخلاف يظل موجودًا بين الفريقين، و اشــتعاله

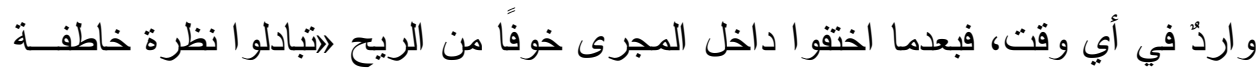

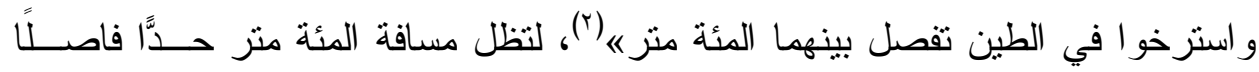

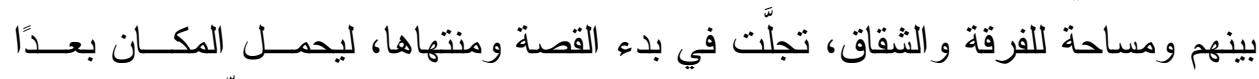

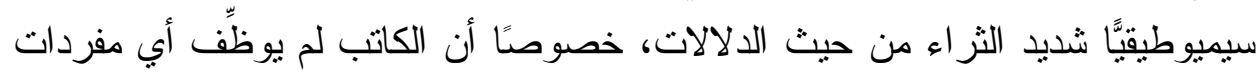

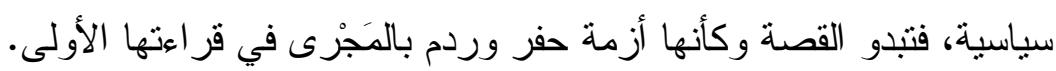

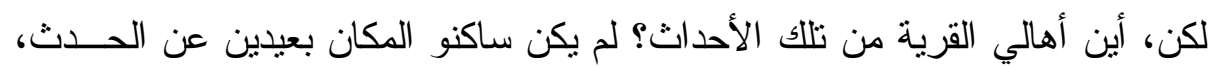

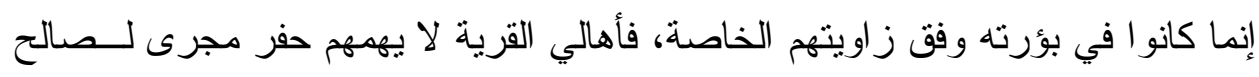

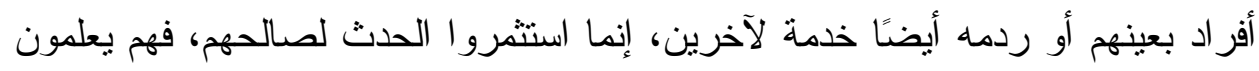


أن أنفار الكر اكة يقبضون رواتب أكثر من الثغيلة في الغيطان وأيديهم سخية ويسأكلون

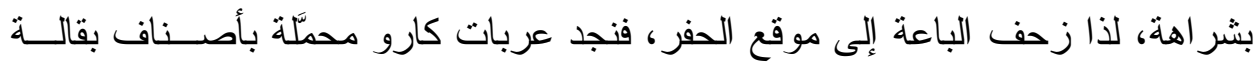

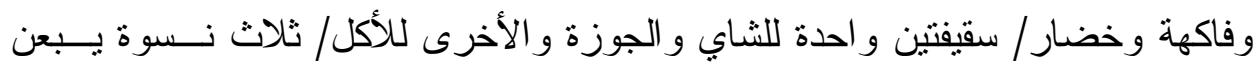

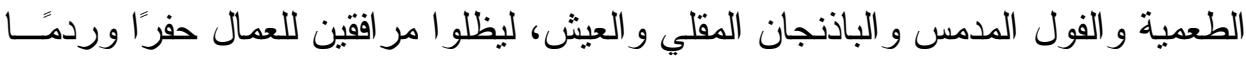

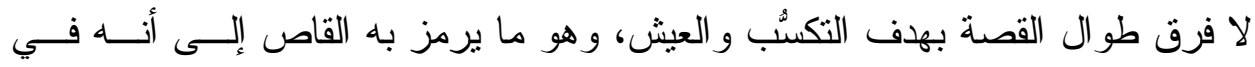

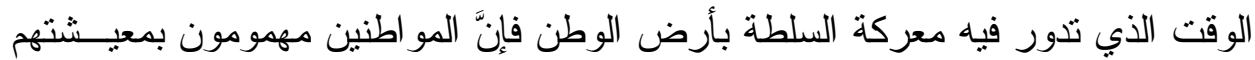

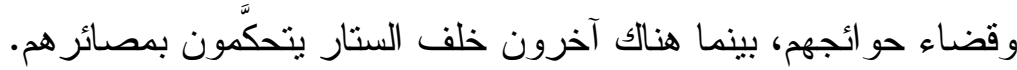

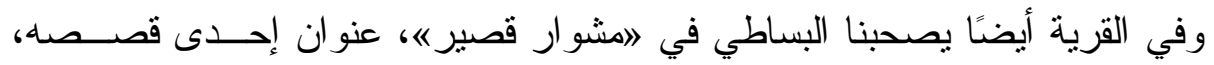

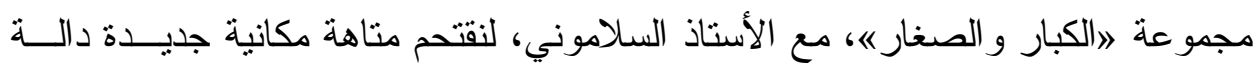

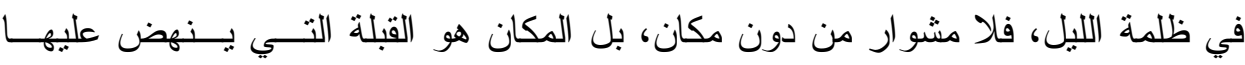

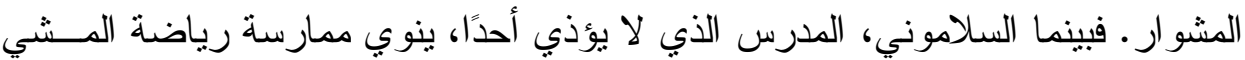

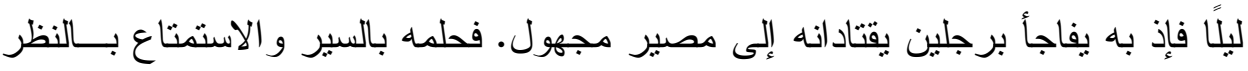

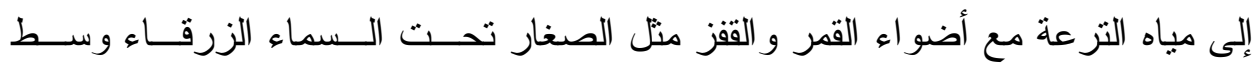

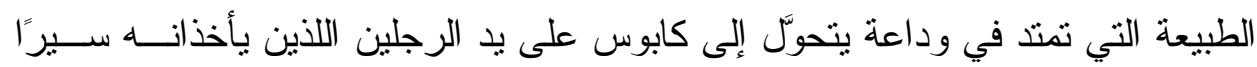

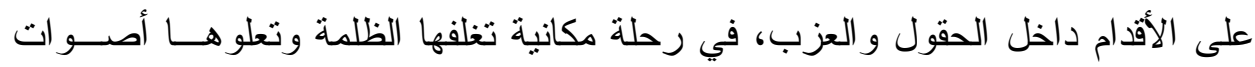
نقيق الضفادع.

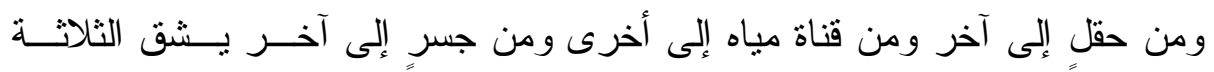

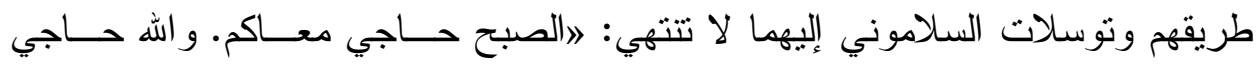

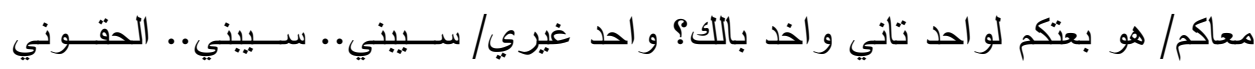

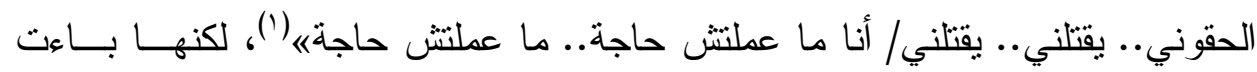

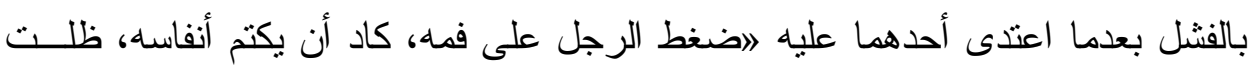

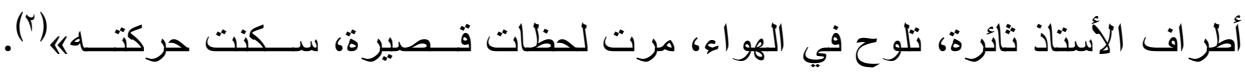

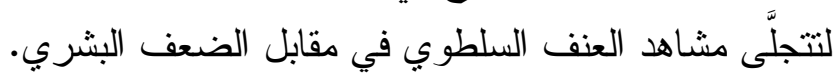

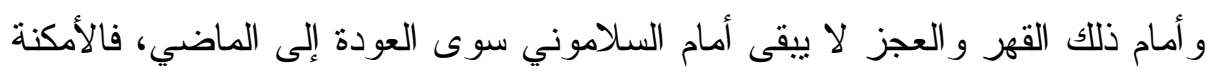

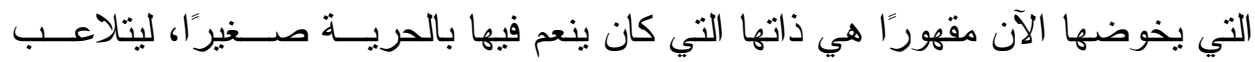


القاص بالطبيعة سيميوطيقيًا بين زمنين: الماضي و الحاضر ، ويجتر عبر الثخصية مـــا

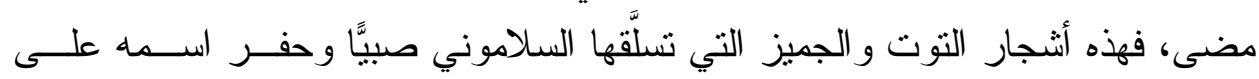

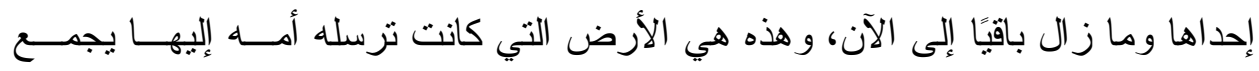

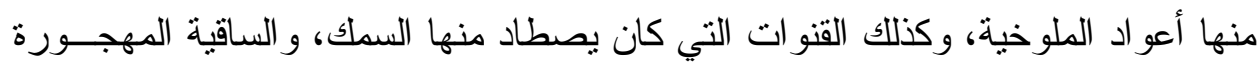

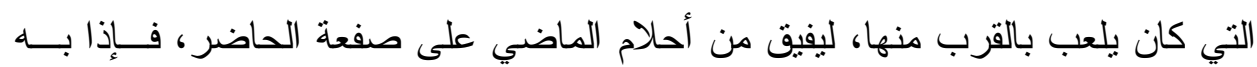

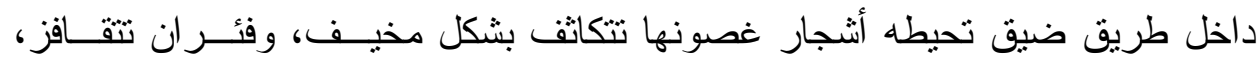

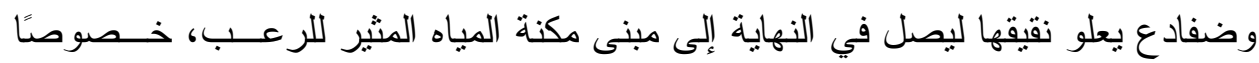

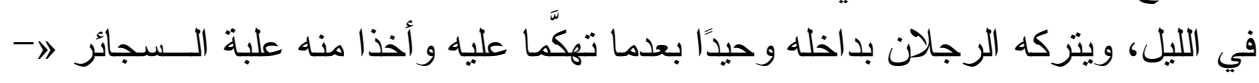

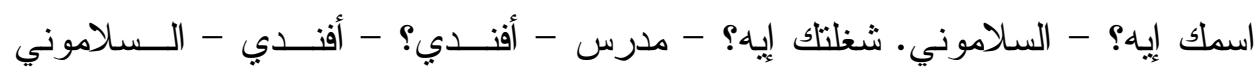
أفندي.. طظه (').

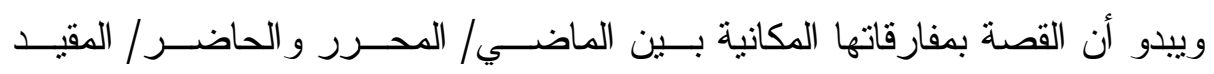

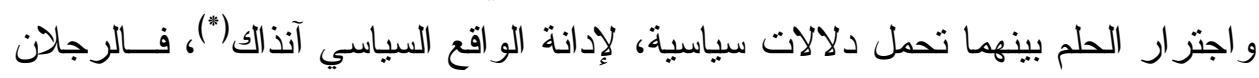

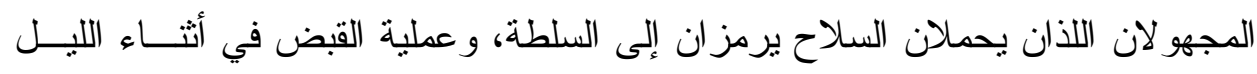

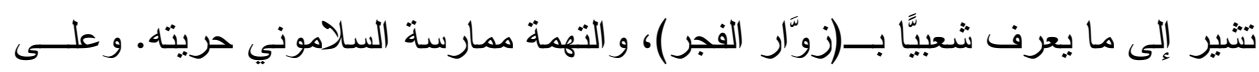

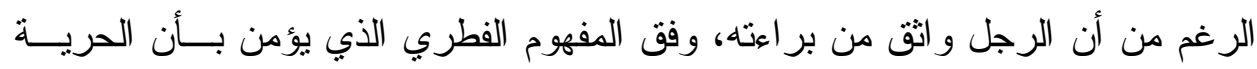

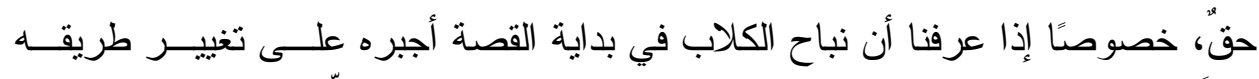

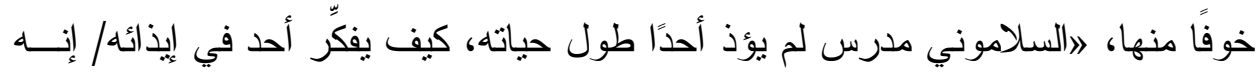

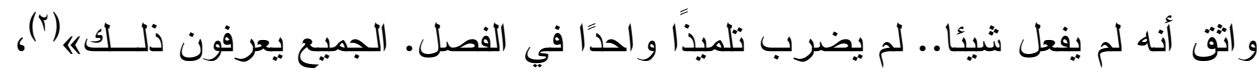

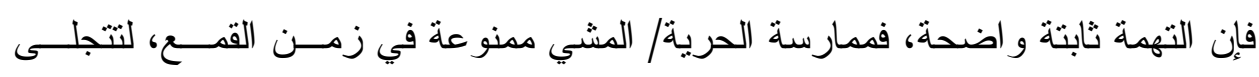
ثنائية السلطة و الحرية، التي يتكرر صداها في كثير من قصص البساطي بشكل خفـيّ،

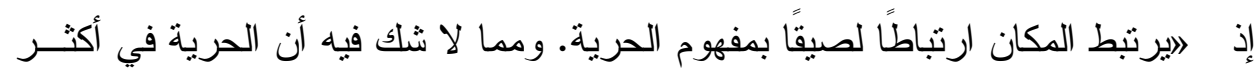
صور ها بدائية هي حرية الحركة. ويمكن القول إن العلاقة بين الإنسان و المكان تظهــر بوصفها علاقة جدلية بين المكان و الحريةه(؟). ليطل المكان بوصفه إدانة لو اقع سياسي.

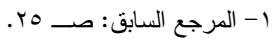

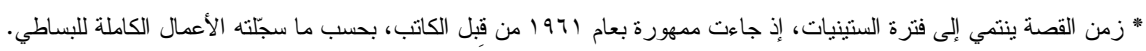

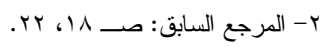

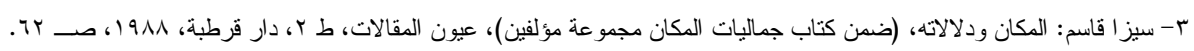




\section{توظيف الطبيعة}

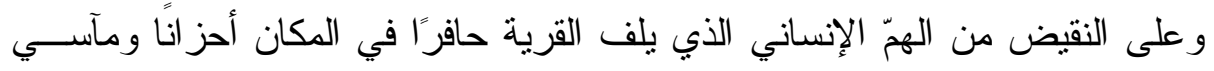

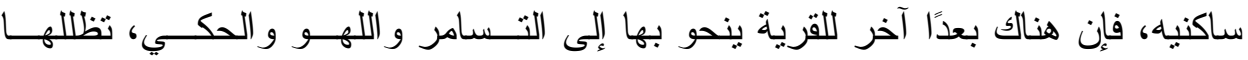

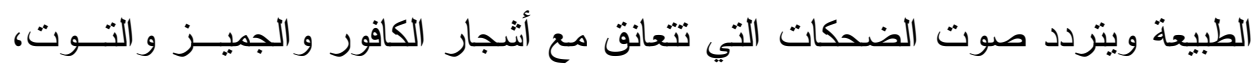

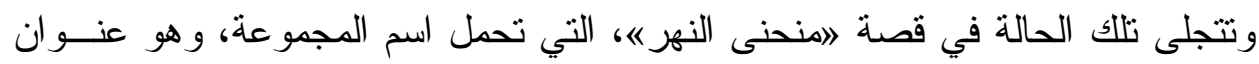

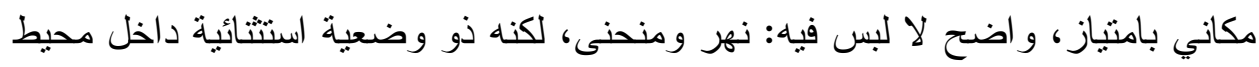

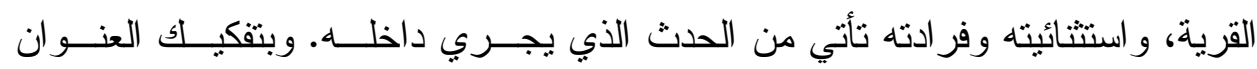

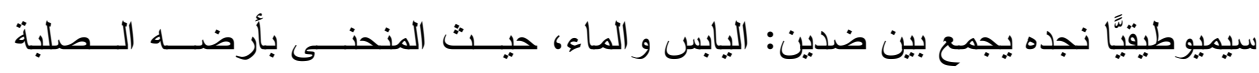

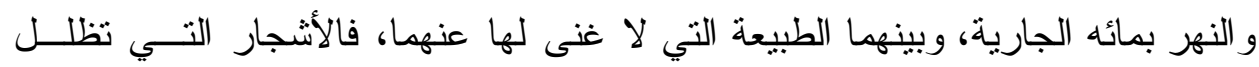

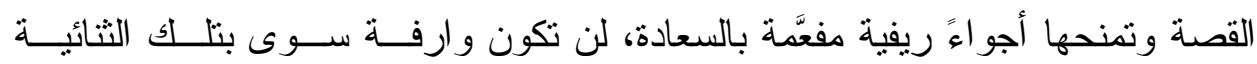
المنضادة: الماء/ النهر و الأرض/ المنحنى، ليخرج الئه عنها الثجر بما يحمله من دلالات.

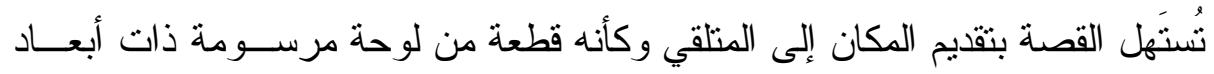

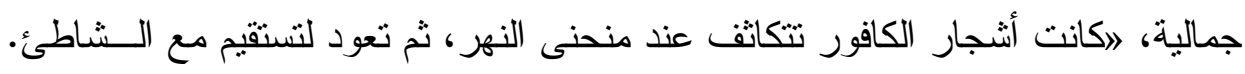

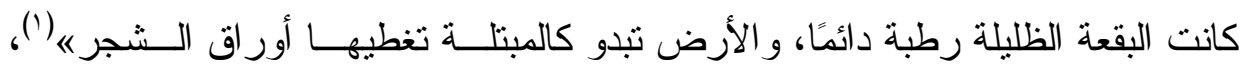
ومركزية المنحنى في القصة أو بالأحرى في البلدة تتجلى في مشاهد الألفة التي رسمها

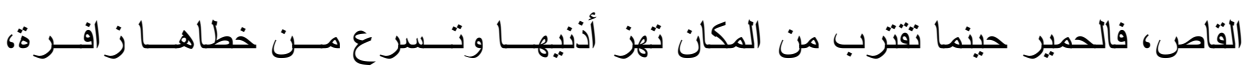

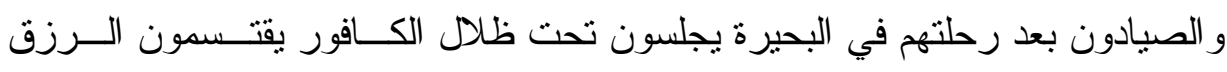

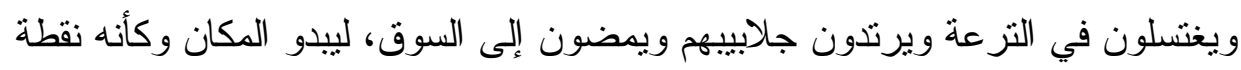

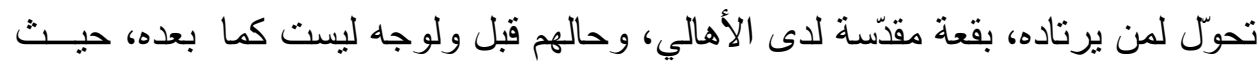
الرزق و الطمأنينة و الهدو و و الضحكانك.

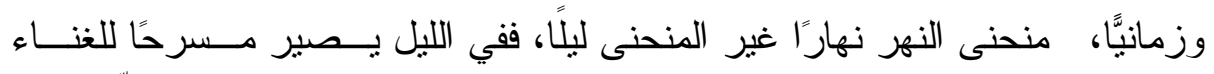

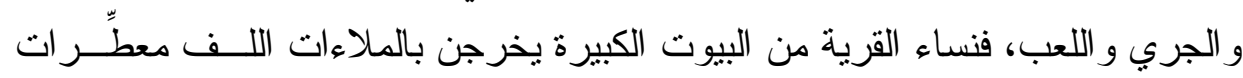

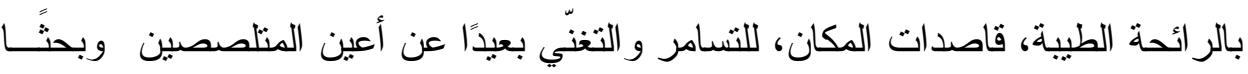

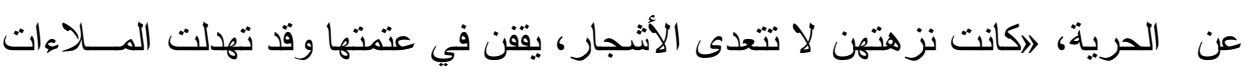

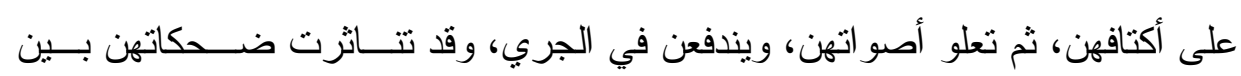


الأثجار "(')، وتبدأ بعدها حفلة غناء على استحياء ممزوجة بخجل ريفي فطــري مــن

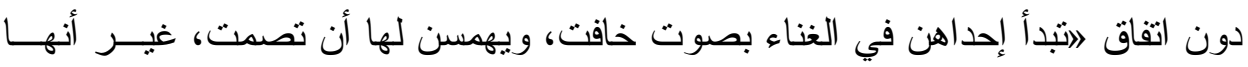

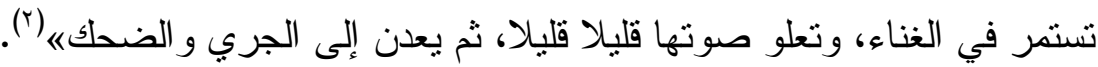

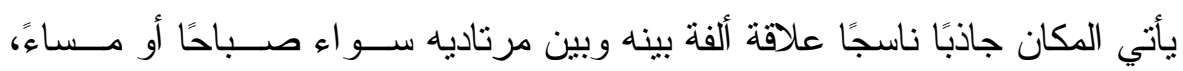

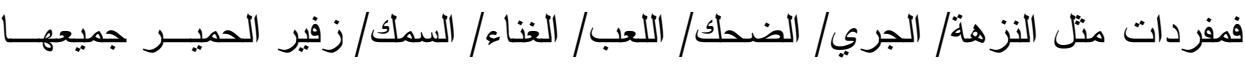

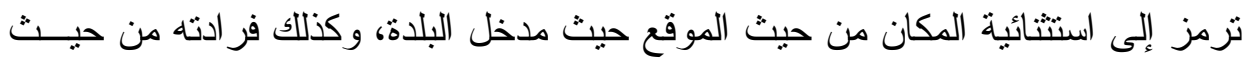

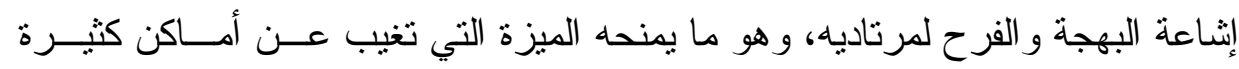

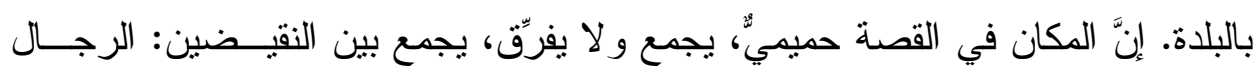
و النساء، الأطفال و الكبار ، حتى الحيو انات.

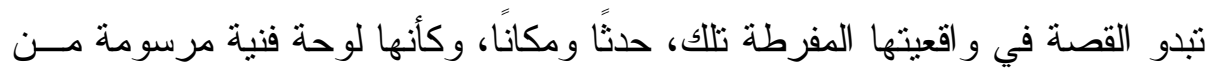

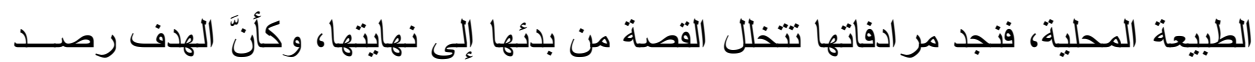

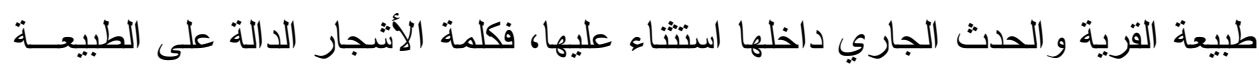

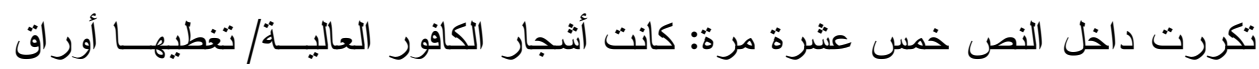

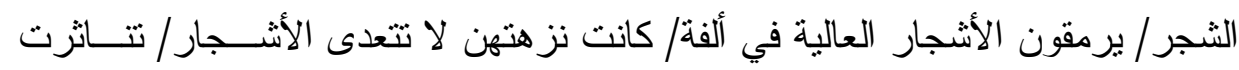

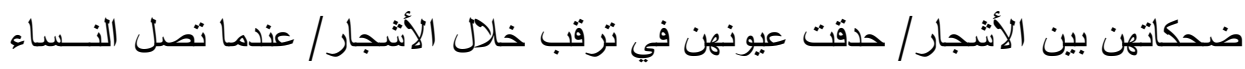

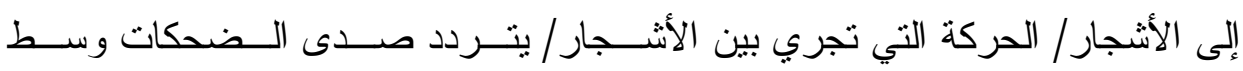

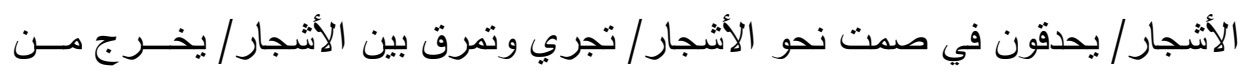

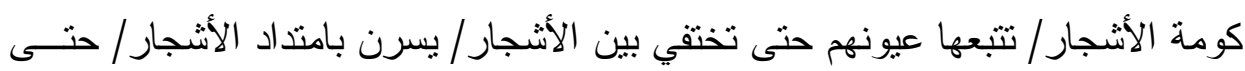

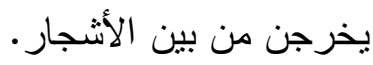

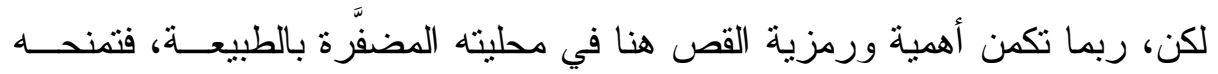

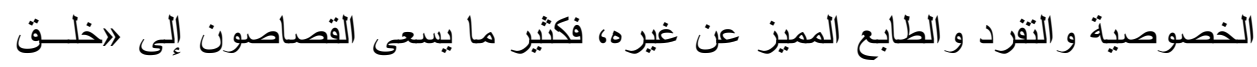

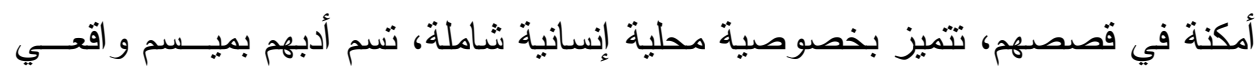

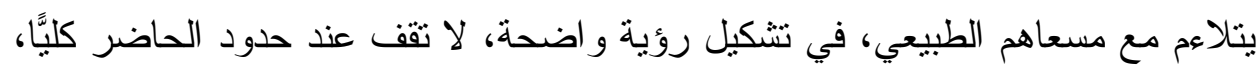

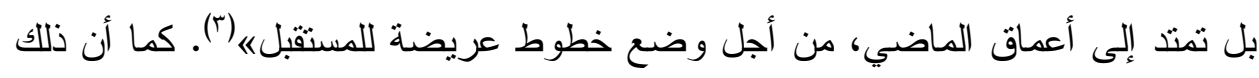

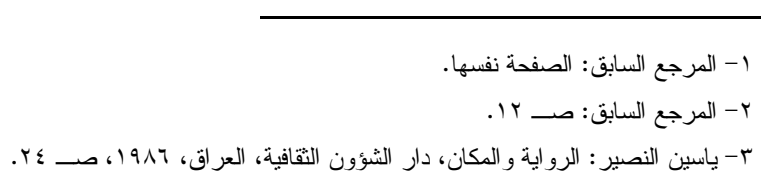


الاقتران بين السلوك الاجتماعي وسط جماليات الطبيعة يكثف عن مدى العقلية الجمعية

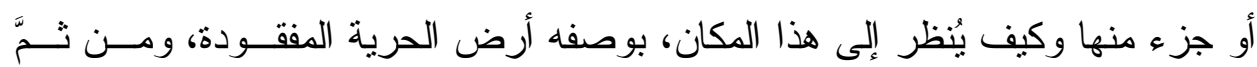
استقر اء المنظومة الثقافية، من خلاء الأثر الذي تتركه الطبيعة و الحدث الجاري بداخلها

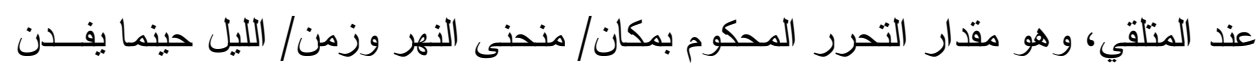

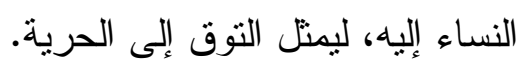
كما أن الطبيعة الموجودة في قصة الهنحنى النهره، حيث أثنجار الكافور و الجميـز

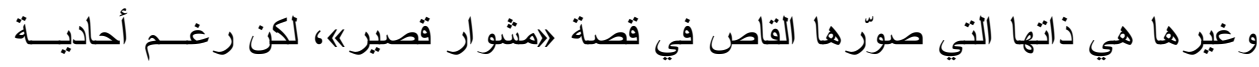

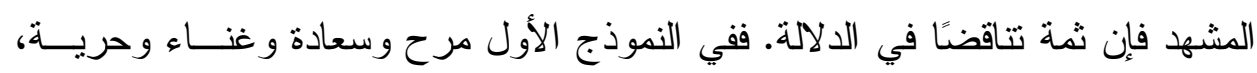

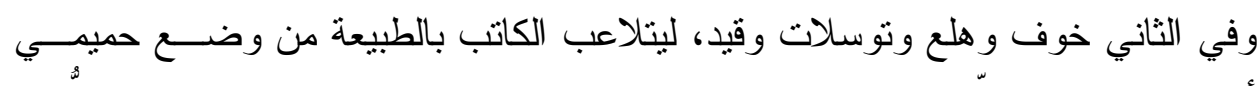

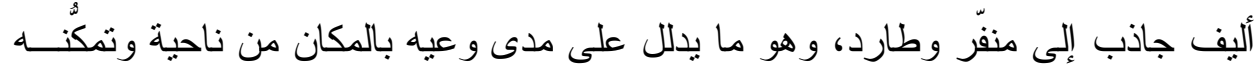

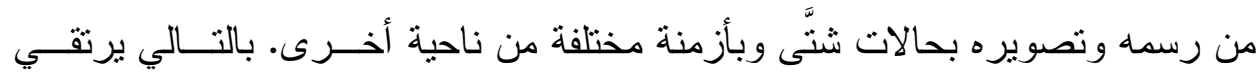

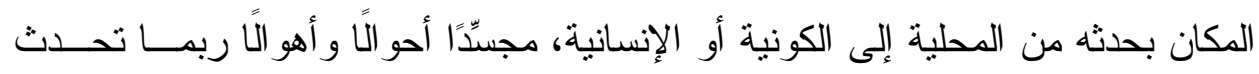
خارج نطاق القرية أو خارج الوطن.

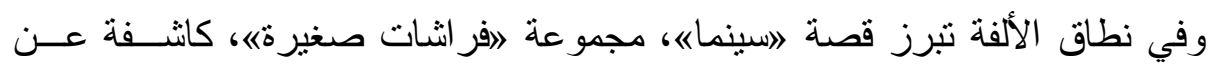

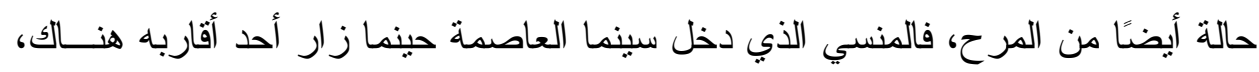

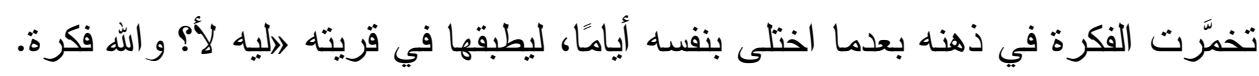

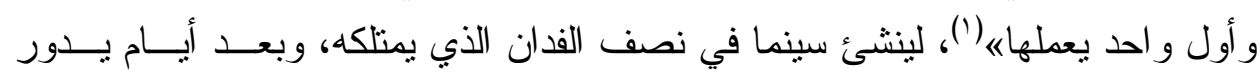
الميكروفون بالبلدة معلنًا عرض أول فيلم بسينما المنسي (إسماعيل يس في الجيش) فيشان.

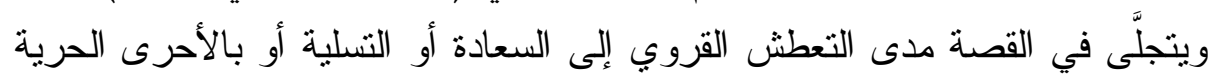

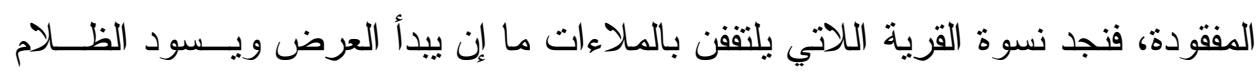

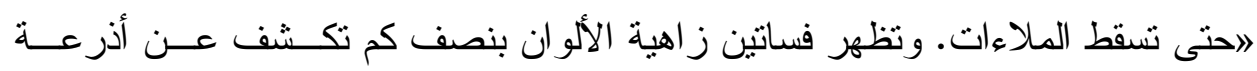

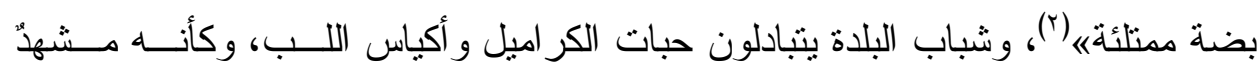

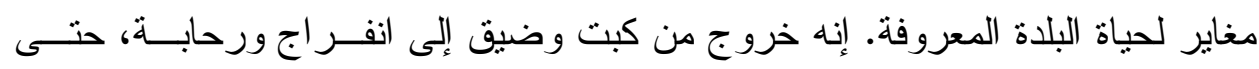

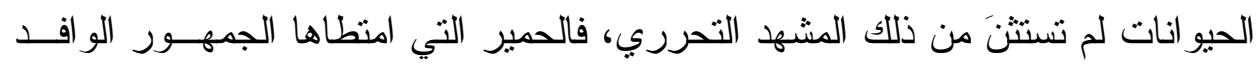

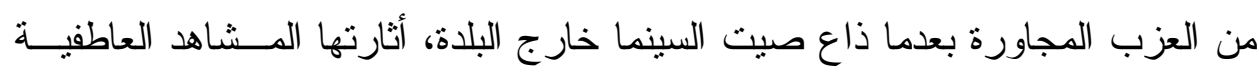


بالأفلام، فتبادلت العض الخفيف في الرقاب، وداعبت بعضها بتلامس الــرؤوس، ليبلــــ

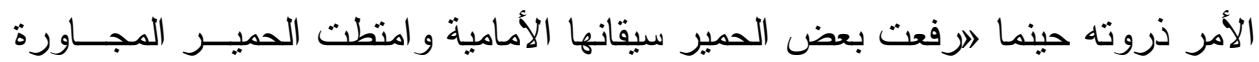

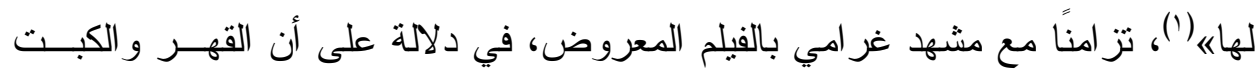

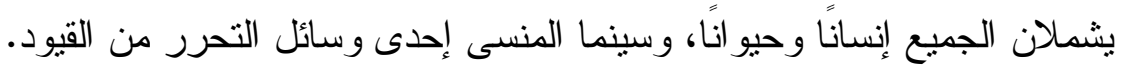

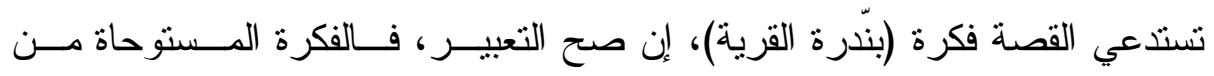

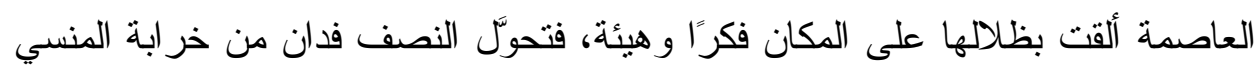

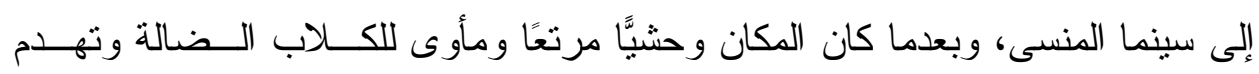

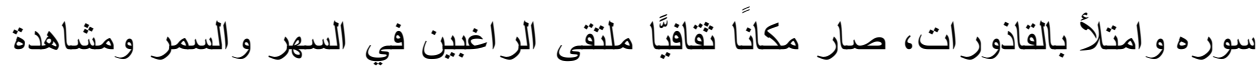

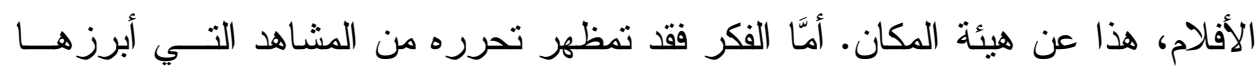
القاص لدى النسوة وتصرفاتهن و إقبالهن على السينما، وكذلك الحمير التي أثنارت دهشة

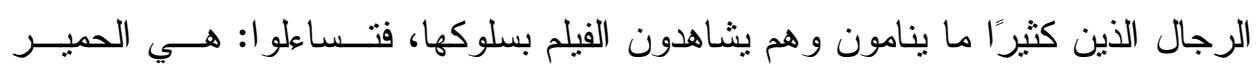

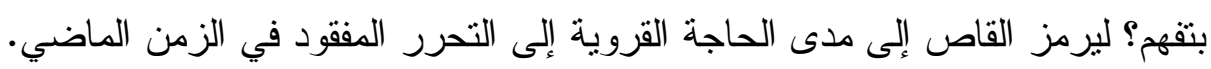

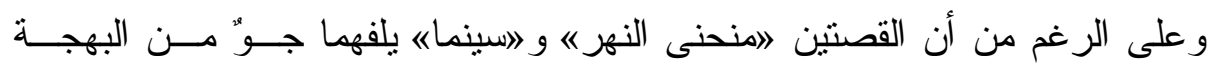

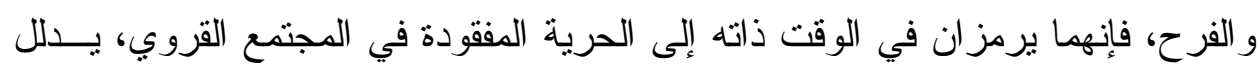

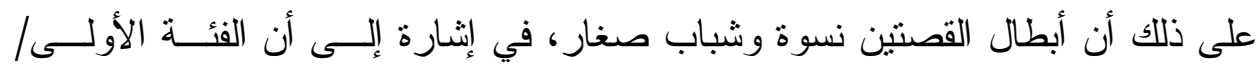

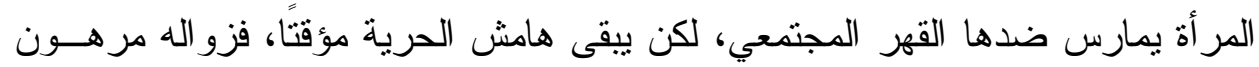

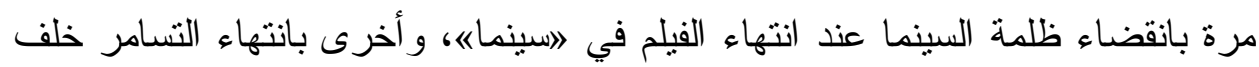

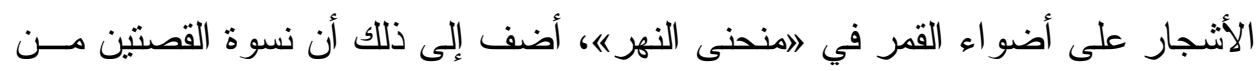

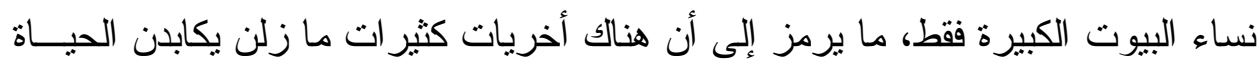

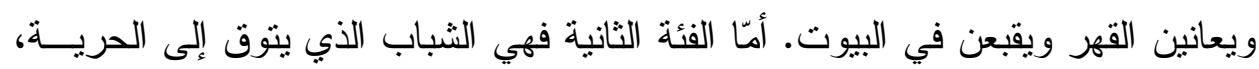

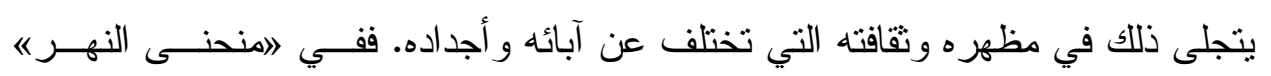

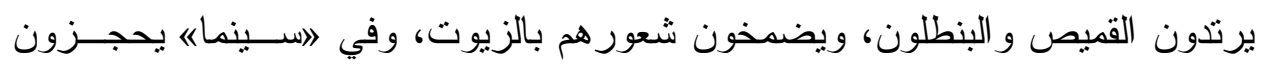

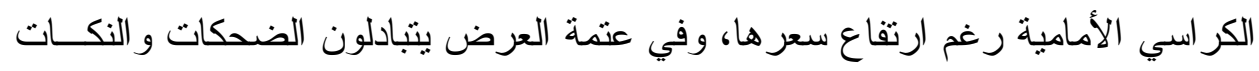
ومأكو لات التسالي، ناهيك بالحمير ودلالة سلوكها في القصتين.

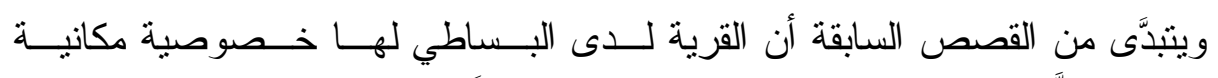

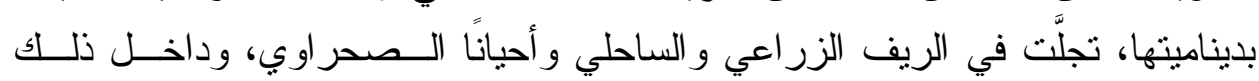




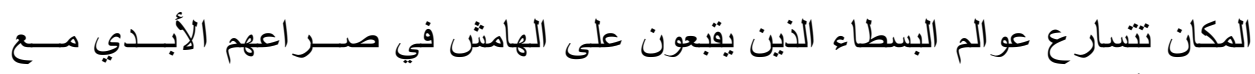

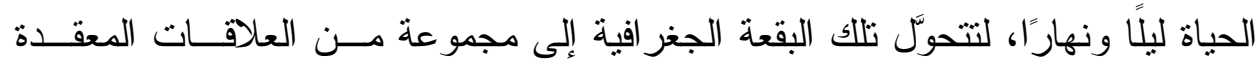

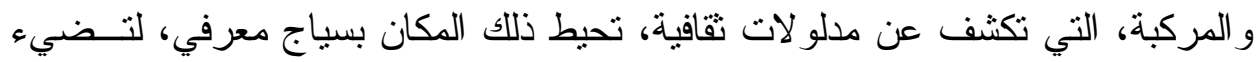

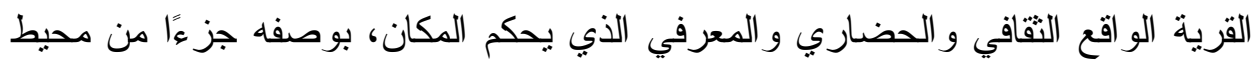
تقافي أكبر هو مصر.

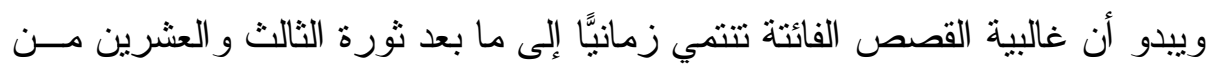

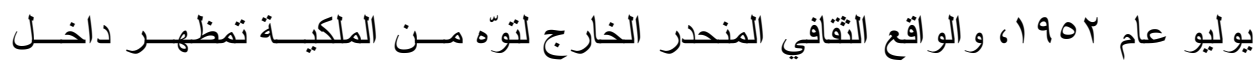

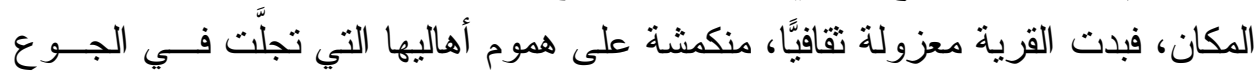

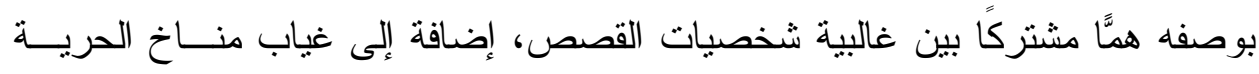

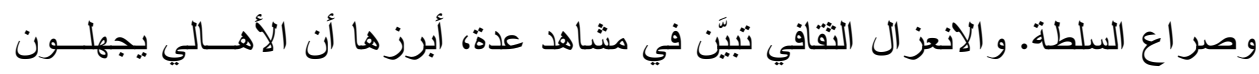

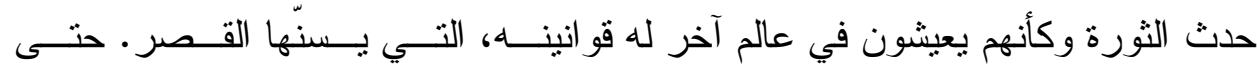

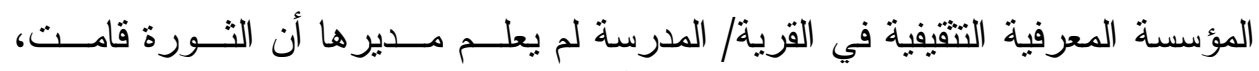

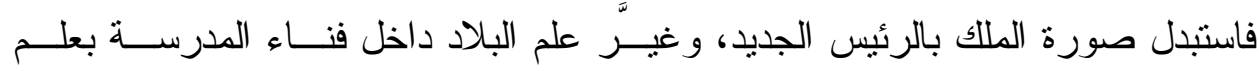
الثورة، بعدما فوجئ بالقوة الأمنية التي هبطت إلى البلى البلدة.

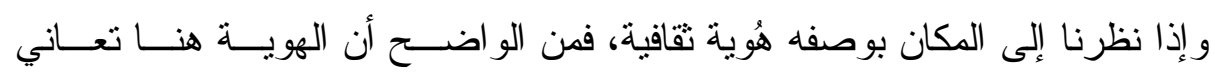

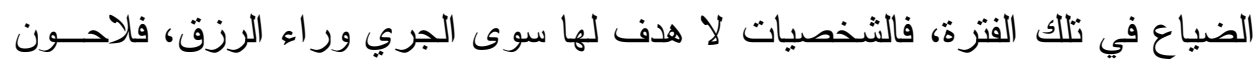

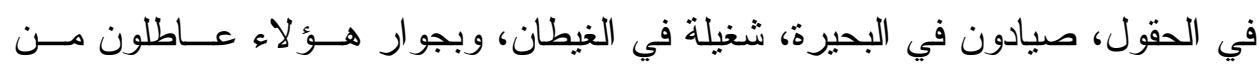

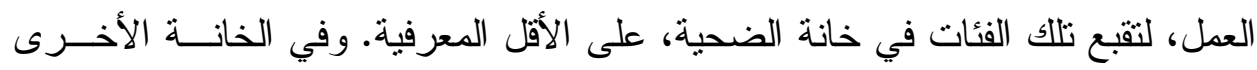

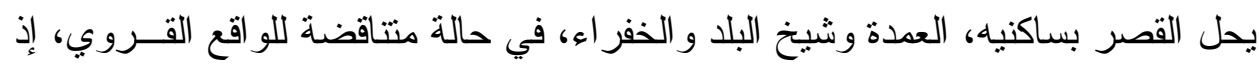

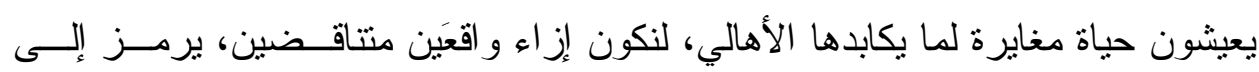

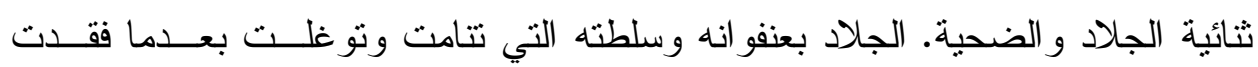

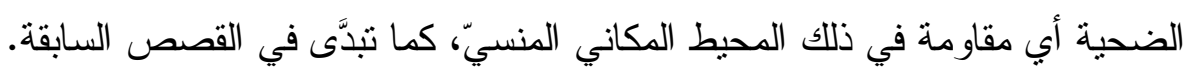

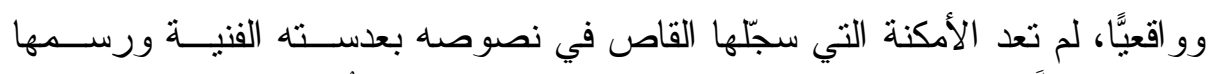

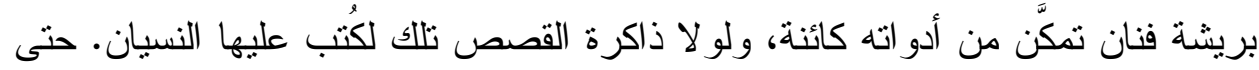

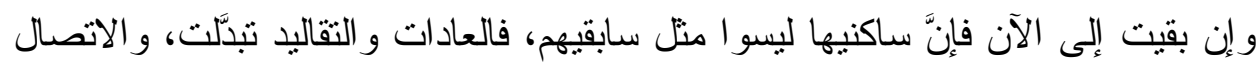

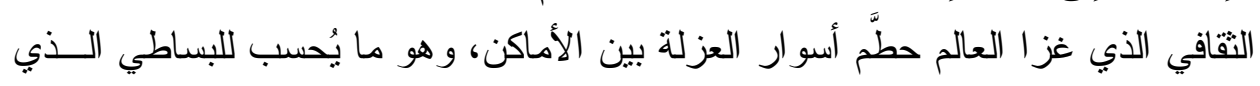

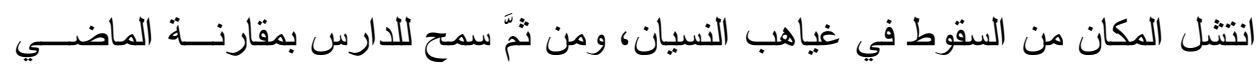


بالحاضر واستقر اء أيديولوجيات البشر ، وسيكولوجيتهم، ومعرفة تحوّلات المكان ثقافيَّا

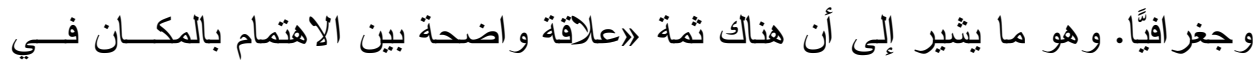

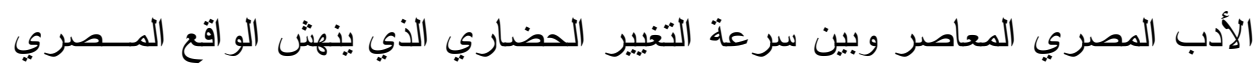

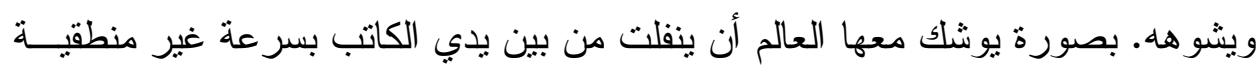

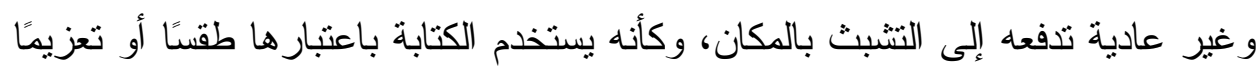

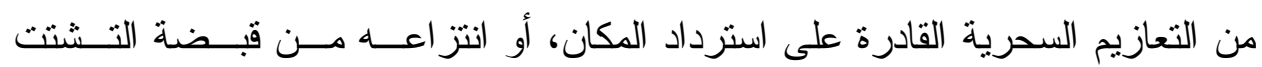
و الضياعه ('). 
تميّزت قرية البساطي بأنها جمعت في طياتها ثناثنة أمكنة نادرًا مـــا تتهيـأ لقـاصٍ

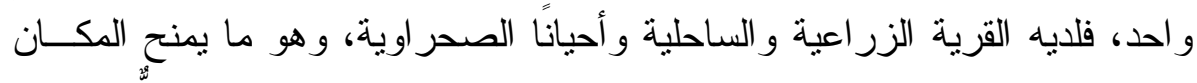

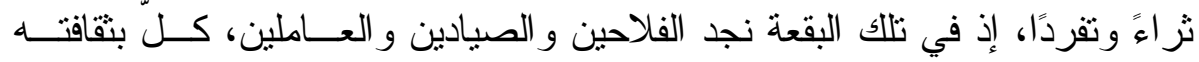
و أسلوبه وحياته.

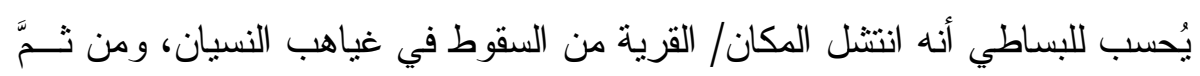

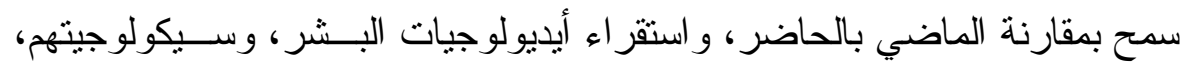

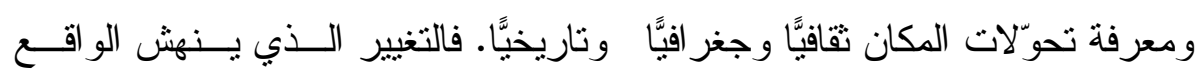
المصري لن يصمد أمامه سوى ذلك المنجز الإبداعي الذي ينتبث بالمكان محاونًا انتز اعه من قبضة الضياع.

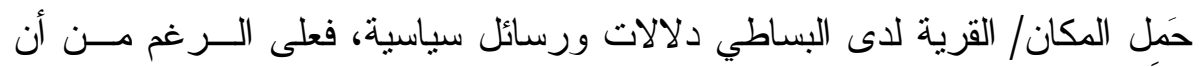

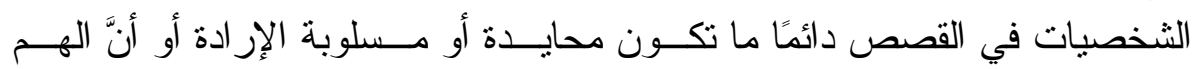

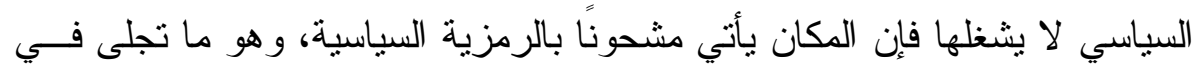

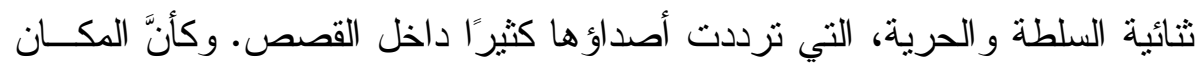

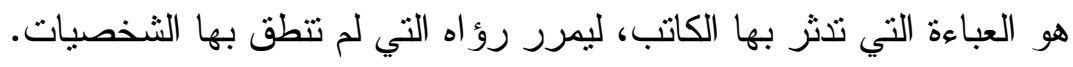

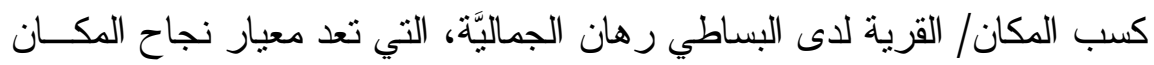

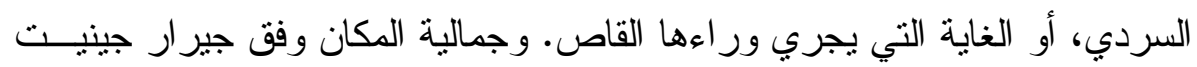

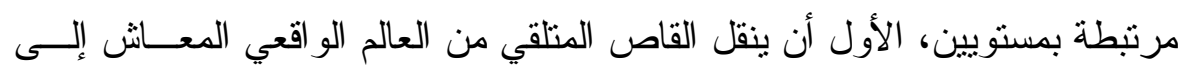

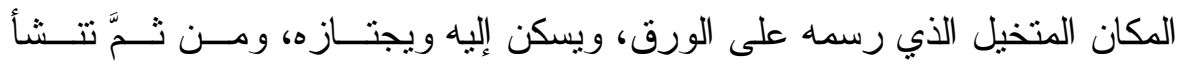

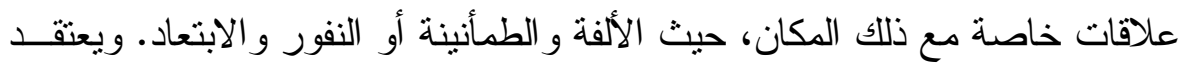

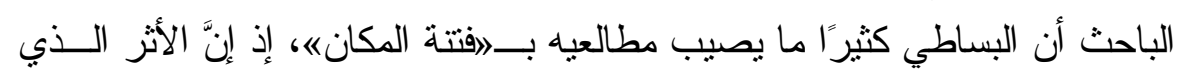
يبقى من غالبية قصصه هو المكان الذي احتوى الحدث، الذي يستجيب إليه المتلقي

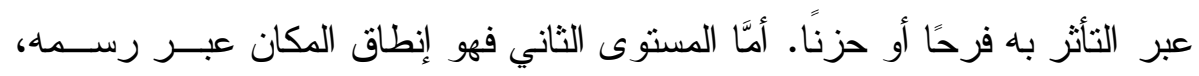

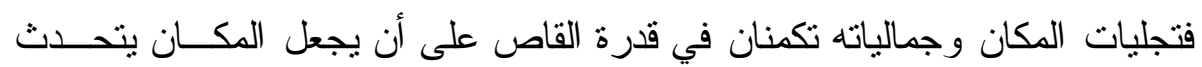
بنفسه، لا أن يتحدث الكاتب عنه. 
" كثفت القرية لدى البساطي المنظومة الثقافية التي تحكم تلاك البقعة آنذالك، ومـدى

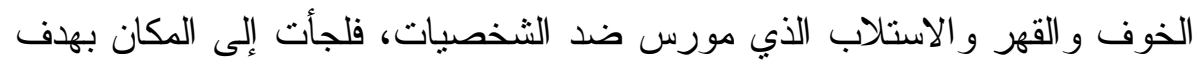
الاحتماء و الاختباء من ذلك القهر . 


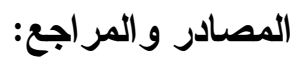

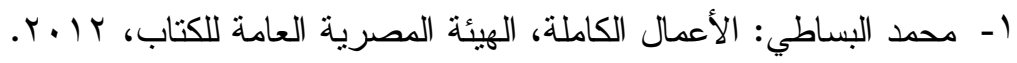

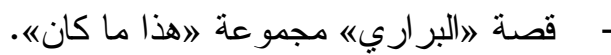

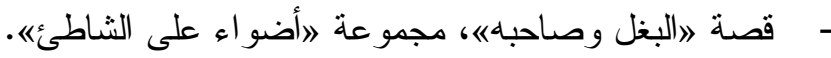

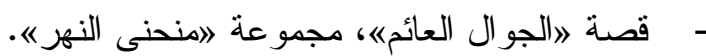

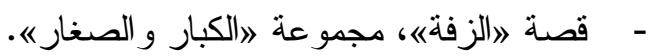

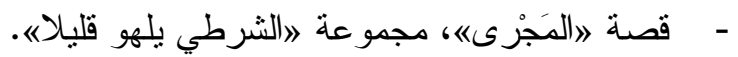

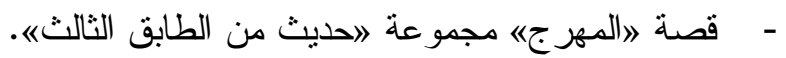

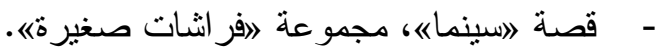

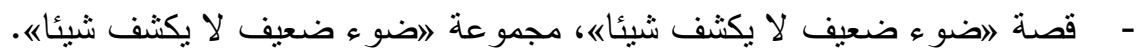

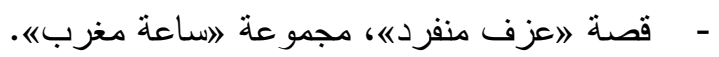

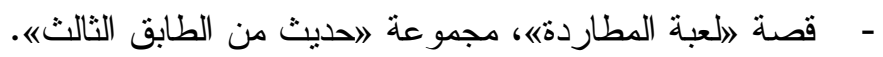

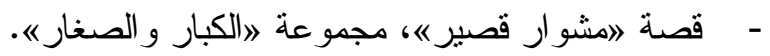

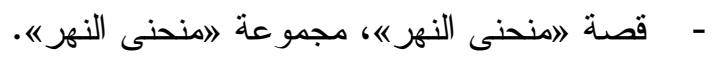

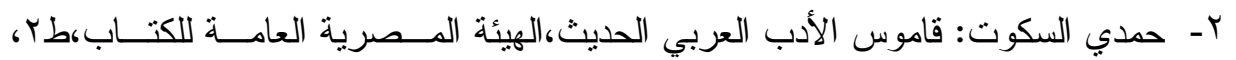
.$r .10$ r- سيز ا قاسم: المكان ودلالاته، (ضمن كتاب جماليات المكان مجموعة مــؤلفين). عيــون

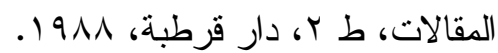

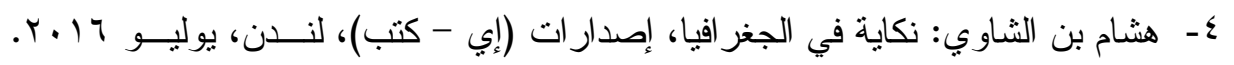
ط 1 b

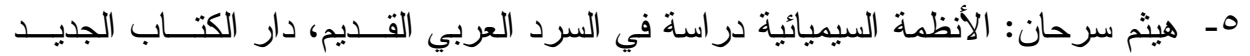

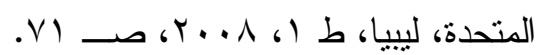

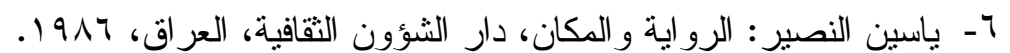
المجلات و الدوريات

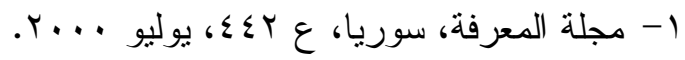

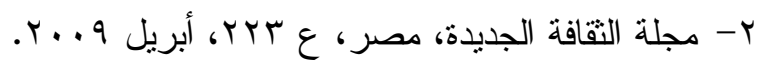

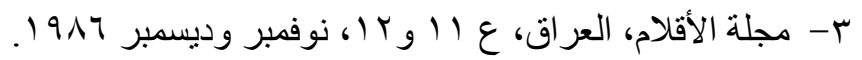


